POSTGLACIAL VOLCANIC DEPOSITS AT MOUNT BAKER, WASHINGTON AND POTENTIAL HAZARDS FROM FUTURE ERUPTIONS 


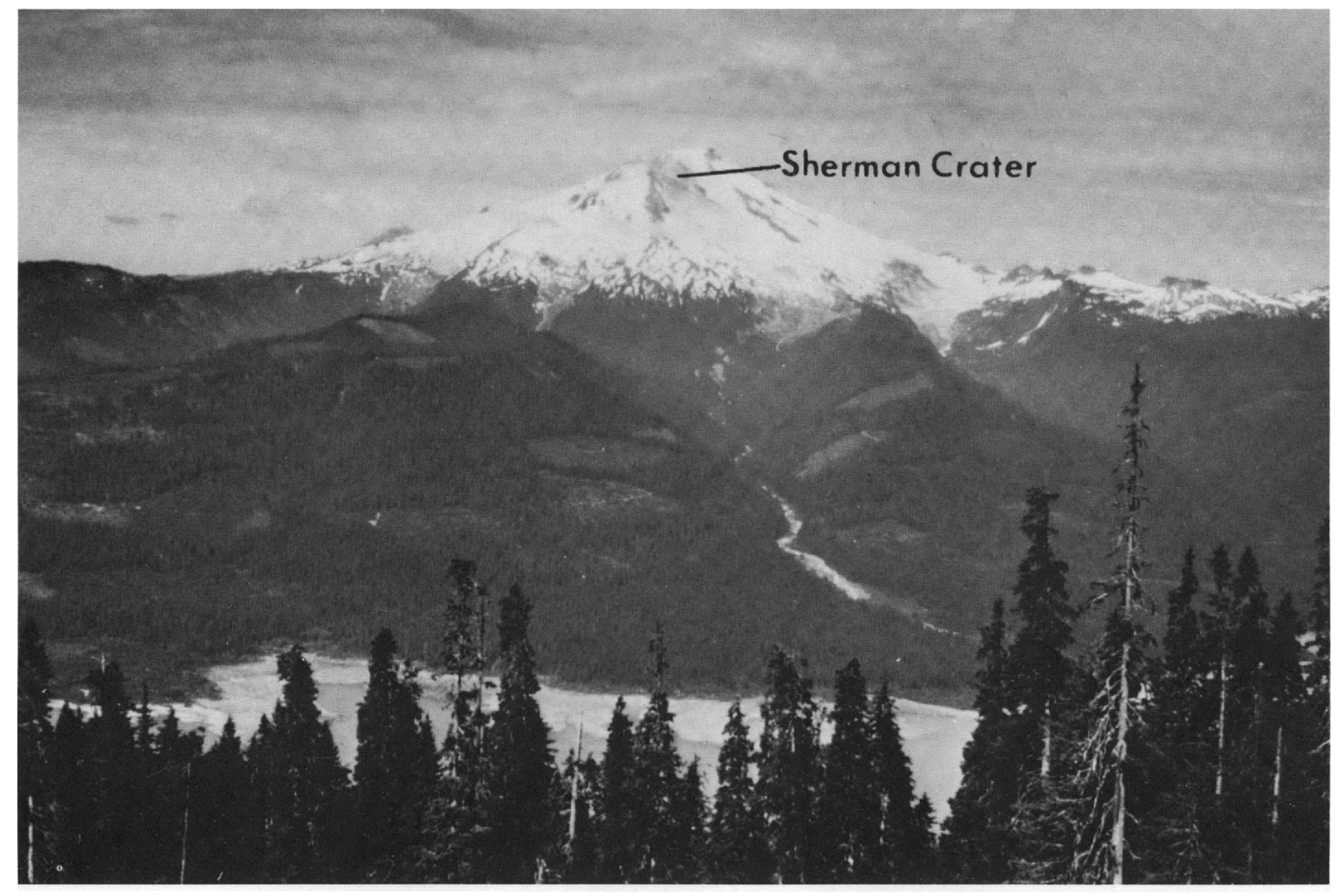

Frontispiece. - East side of Mount Baker. Boulder Creek, in the center of the photograph, flows into Baker Lake. 


\section{Postglacial Volcanic Deposits at Mount Baker, Washington, and Potential Hazards from Future Eruptions}

By JACK H. HYDE and DWIGHT R. CRANDELL

VOLCANIC ACTIVITY AT MOUNT BAKER, WASHINGTON GEOLOGICAL SURVEY PROFESSIONAL PAPER $1022-\mathrm{C}$

An assessment of potential hazards at Mount Baker is based on the volcano's eruptive behavior during the last 10,000 years

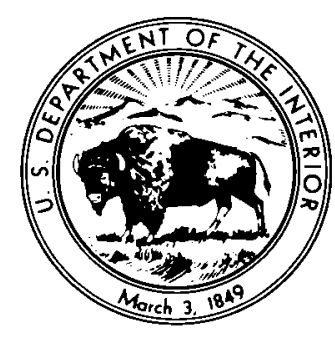




\section{UNITED STATES DEPARTMENT OF THE INTERIOR \\ CECIL D. ANDRUS, Secretary}

\section{GEOLOGICAL SURVEY}

H. William Menard, Director

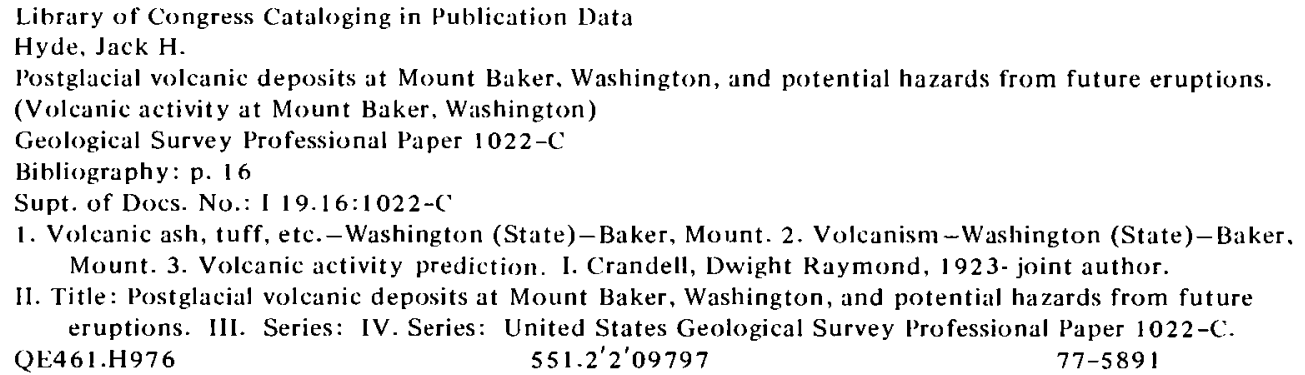

For sale by the Superintendent of Documents, U.S. Government Printing Office Washington, D.C. 20402

Stock Number 024-001-03089-6 


\section{CONTENTS}

\begin{tabular}{|c|c|c|c|}
\hline & Page & & Page \\
\hline Abstract & $\mathrm{C} 1$ & Description of deposits-Continued & \\
\hline Terminology & 3 & Potential geologic hazards & 10 \\
\hline Description of deposits & 3 & Mudflows and avalanches of rock debris & 11 \\
\hline 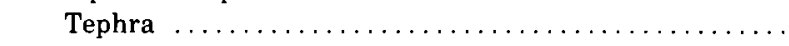 & 3 & 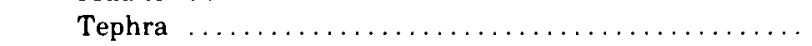 & 12 \\
\hline Boulder Creek valley $\ldots \ldots \ldots \ldots \ldots \ldots \ldots \ldots \ldots$ & 5 & Pyroclastic flows & 12 \\
\hline Sulphur Creek valley $\ldots \ldots \ldots \ldots \ldots \ldots \ldots \ldots \ldots$ & 9 & References cited & 16 \\
\hline
\end{tabular}

\section{ILLUSTRATIONS}

FrontisPIECE. East side of Mount Baker.

Plate

1. Areas of potential hazard from tephra, avalanches, mudflows, and floods

In pocket

Figure

1. Index map of the Mount Baker area, Washington ....

2. Photograph of post-Mazama black ash near Table Mountain

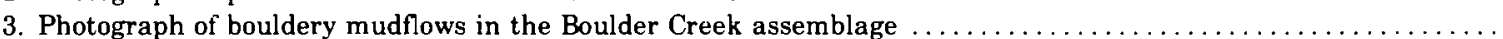

4. Photograph of andesite lava flow overlying mudflow in the Boulder Creek assemblage $\ldots \ldots \ldots \ldots \ldots \ldots \ldots$

5. Photograph of clayey mudflow overlying fluvial gravel in bank of Boulder Creek . . . . . . . . . . . . . . .

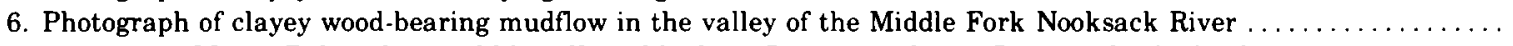

7. Areas near Mount Baker that could be affected by lava flows, pyroclastic flows, and ash clouds ..............

8. Average frequency of winds in northwestern Washington.

\section{TABLES}

2. Composition of postglacial tephra at Mount Baker

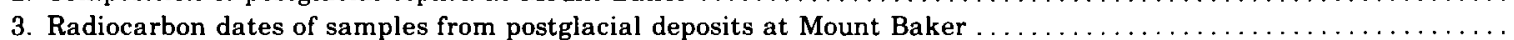

4. Large postglacial avalanche and mudflows of altered rock debris from Mount Baker $\ldots \ldots \ldots \ldots \ldots \ldots \ldots \ldots$

5. Average wind speeds at various altitudes

6. Average percentage of wind directions, by month, at altitudes of about $3.000 \cdots 16.000 \mathrm{~m}$, averaged 



\title{
POSTGLACIAL VOLCANIC DEPOSITS AT MOUNT BAKER, WASHINGTON, AND POTENTIAL HAZARDS FROM FUTURE ERUPTIONS
}

\author{
By Jack H. Hyde and Dwight R. Crandell
}

\begin{abstract}
Eruptions and other geologic events at Mount Baker during the last 10,000 years have repeatedly affected adjacent areas, especially the valleys that head on the south and east sides of the volcano. Small volumes of tephra were erupted at least four times during the past 10,000 years. Future eruptions like these could cause as much as 35 centimeters of tephra to be deposited at sites 17 kilometers from the volcano, 15 centimeters of tephra to be deposited 29 kilometers from the volcano, and 5 centimeters, 44 kilometers from the volcano. Lava flows were erupted at least twice during the last 10,000 years and moved down two valleys. Future lava flows will not directly endanger people because lava typically moves so slowly that escape is possible. Hot pyroclastic flows evidently occurred during only one period and were confined to the Boulder Creek valley. Such flows can move at speeds of as much as 150 kilometers per hour and can bury valley floors under tens of meters of hot rock debris for at least 15 kilometers from the volcano. Large mudflows, most of which contain hydrothermally altered rock debris, originated at Mount Baker at least eight times during the last 10,000 years. The largest mudflow reached 29 kilometers or more down the valley of the Middle Fork Nooksack River, west of the volcano, about 6,000 years ago. Extensive masses of hydrothermally altered rock that are potentially unstable exist today near the summit of the volcano, especially in the Sherman Crater-Sherman Peak area. Avalanches of this material could be triggered by stream explosions, earthquakes, or eruptions, or may occur because of slow-acting forces or processes that gradually decrease stability. Large avalanches could move downslope at high speed and could grade downvalley into mudflows. Floods caused by rapid melting of snow and ice by lava or by hot rock debris could affect valley floors many tens of kilometers from the volcano and could have especially severe effects if they were to occur at a time of flooding resulting from rapid snowmelt or heavy rains.
\end{abstract}

\section{INTRODUCTION}

Mount Baker is a large stratovolcano in northwestern Washington about $30 \mathrm{~km}$ (kilometers) east of Bellingham and $25 \mathrm{~km}$ south of the International Boundary (fig. 1). The glacier-covered cone of andesite lava flows and breccias rises $2 \mathrm{~km}$ above adjacent mountains carved from a complex of older sedimentary and metamorphic rocks (Coombs, 1939; Misch, 1966). The present cone was formed prior to the last major glaciation (Fraser Glaciation), which occurred between about 25,000 and 10,000 years ago (Armstrong and others, 1965; Halstead, 1968; Heusser, 1974), and probably is considerably older. The cone overlaps rocks of an earlier eruptive center (Coombs, 1939) from which two radiometric dates of about 400,000 years have been obtained (Easterbrook and Rahm, 1970).
The purpose of this report is to describe the postglacial eruptive history of the volcano as it is recorded by deposits of volcanic origin and to appraise and forecast the hazards that could result if similar eruptions were to occur in the future. The report is based on about 2 months' fieldwork in 1973 and 1974 by Hyde, who is chiefly responsible for the interpretation of the origin, stratigraphy, and distribution of the postglacial volcanic deposits at Mount Baker. Crandell briefly examined the distribution and thickness of tephra deposits near the volcano in 1975 , aided in the assessment of potential volcanic hazards presented in an earlier report (Hyde and Crandell, 1975), and prepared this revision of that report.

The investigation was mostly limited to the east and southwest sides of the volcano, where postglacial deposits derived from Mount Baker are concentrated. Small mudflow deposits are present in the Glacier and Bar Creek valleys on the north side of the volcano (fig. 1), but the lithology of these deposits indicates that they were derived from the sedimentary and metamorphic basement rocks, rather than from the volcanic rocks of Mount Baker.

Mount Baker is drained on the north by streams flowing into the North Fork Nooksack River, on the west by the Middle Fork Nooksack River, and on the southeast and east by tributaries of the Baker River (fig. 1), which empties into the Skagit River about 14 $\mathrm{km}$ southeast of Mount Baker. The Baker River is impounded by two dams; the upper dam is near the mouth of the Sulphur Creek valley and forms Baker Lake, and the lower dam is about $12 \mathrm{~km}$ farther downvalley and forms Lake Shannon.

Mount Baker's summit crater is covered by snow and ice, and little is known of its nature or age. A prominent crater partly filled with ice, known as Sherman Crater (fig. 1; Frank and others, 1975), is $350 \mathrm{~m}$ (meters) lower than, and about $800 \mathrm{~m}$ south of, the summit. Its east rim, above the head of Boulder Glacier, is breached by a notch about $150 \mathrm{~m}$ deep. Another low point, about 100 $m$ deep, is on the southwest rim above Deming Glacier. Fumaroles and thermal springs are concentrated in the crater, where solfataric and hydrothermal activity has produced clay minerals and other alteration products 
VOLCANIC ACTIVITY AT MOUNT BAKER. WASHINGTON

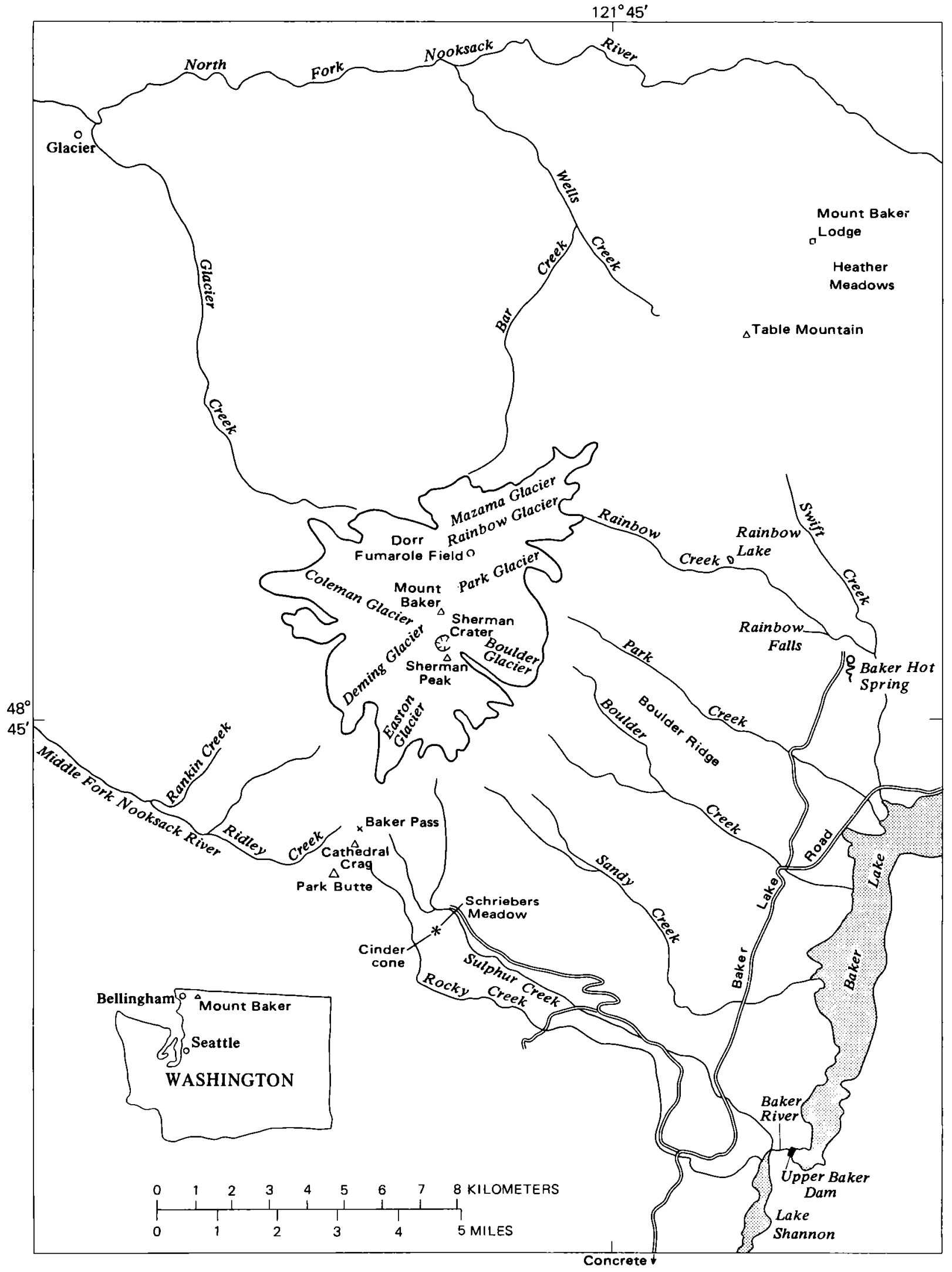

Figure 1. - Index map of the Mount Baker area, Washington. 
(Coombs, 1939; Frank and others, 1975; Bockheim and Ballard, 1975). Avalanches of snow, firn, and hydrothermally altered rock debris from the rim of Sherman Crater have swept down Boulder Glacier at least six times since 1958 (Frank and others, 1975).

Most hydrothermal activity at Mount Baker is concentrated within Sherman Crater, although a small area of fumaroles, known as the Dorr Fumarole Field, is present on the north flank of the volcano at an altitude of 2,300 to $2,500 \mathrm{~m}$. The activity at Sherman Crater increased significantly in March 1975 and caused concern that an eruption might be imminent (Malone and Frank, 1975). As a result, various kinds of geophysical and geochemical monitoring were undertaken in the expectation that if an eruption occurred it would be preceded by other kinds of events. The hydrothermal activity and the monitoring of the volcano from March 1975 to March 1975 are summarized in a companion report (Frank and others, 1977).

Mount Baker was active on several occasions during the 19th century (Malone and Frank, 1975), but no volcanic deposits which could definitely be attributed to historic eruptions were identified during the present in. vestigation.

\section{TERMINOLOGY}

The term "tephra" is used here to refer to fragmental volcanic-rock debris ejected from a volcanic vent and transported through the air (Thorarinsson, 1954). Tephra consists of pumice or scoria, mineral crystals, dense rock fragments, or a mixture of these. Both pumice and scoria are vesicular, which means that they have a large amount of visible pore space. Scoria is somewhat less vesicular than pumice and is typically dark gray or brown, whereas pumice is generally white or yellow. Ash is tephra that consists of particles less than $2 \mathrm{~mm}$ (millimeters) in diameter.

A pyroclastic flow is a hot dry flow of volcanic-rock debris mixed with air and other gases that moves down the side of a volcano. Such a flow may extend for many kilometers beyond a volcano's base, and an accompanying cloud of hot dust may rise above the flow to heights of hundreds or thousands of meters. These hot mixtures of rock debris and gas can travel at speeds of 50 to at least $150 \mathrm{~km} / \mathrm{hr}$ (kilometers per hour). The downslope movement of pyroclastic flows is due chiefly to gravity, although the explosive force of an eruption may provide a high initial velocity. Air trapped within the debris and heated, hot gases emitted by rock fragments in the flow, or both, give pyroclastic flows a high degree of mobility. The resulting deposits may consist of pumice, dense rock fragments, or mixtures of both. Pyroclastic flows commonly are caused by eruptions of explosive gas-rich magma. Flows consisting mainly of nonvesicular rock fragments generally originate from avalanches of newly erupted hot rock debris on the sides of the volcano or from the collapse of parts of a growing volcanic dome or spine.

Ash-cloud deposits are formed from the clouds of airborne dust that accompany pyroclastic flows (Crandell and Mullineaux, 1973). Ash-cloud deposits, which are more restricted in areal extent than tephra erupted directly by the volcano and carried downwind, generally change greatly in thickness and grain size within a few kilometers of the margin of the pyroclastic flow to which they are genetically related. Ash-cloud deposits consist mostly of lithic ash, but pumice is also common.

A mudflow is a mass of water-saturated rock debris that moves downslope under the force of gravity. Mudflows that originate on volcanoes are also known by their Javanese name, lahars. Rock fragments in a volcanic mudflow may be either hot or cold. Mudflows that originate as a result of eruptions generally are caused by spillover of a crater lake, by rapid melting of snow and ice by hot rock debris and steam, and by volcanic explosions that cause avalanches of moist rock debris. Other mudflows from volcanoes can be caused by the saturation and avalanching of loose rock debris during periods of heavy precipitation, or by avalanching of rock that has been chemically decomposed by hydrothermal activity. In addition, the sudden release of a body of water impounded by a glacier can result in a mudflow as the water moves down the volcano and picks up loose rock debris.

\section{DESCRIPTION OF DEPOSITS}

Postglacial deposits at Mount Baker include tephra, clayey mudflows, lava flows, avalanche deposits, and pyroclastic-flow deposits (table 1). A description of the sequence of deposits in each valley follows a discussion of tephra, which is not confined to a specific area.

\section{TEPHRA}

Tephra that was erupted at Mount Baker during postglacial time formed deposits of small volume which are restricted to the north, east, and south sides of the volcano. In addition, one or possibly two tephra deposits originated at a vent which is now marked by a cinder cone at Schriebers Meadow. The composition of these deposits and their relative ages are shown in table 2 . Mazama ash, which originated at the site of Crater Lake in southern Oregon about 6,600 years ago (Rubin and Alexander, 1960; Powers and Wilcox, 1964), is also present and is a useful stratigraphic marker. This ash can be readily identified by its fine-sandy-silt-size texture and its distinctive yellowish orange appearance. 
TABLE 1. - Summary of postglacial events at Mount Baker

\begin{tabular}{cc} 
Event & $\begin{array}{c}\text { Approximate age, or } \\
\text { limiting dates } \\
\text { (years ago) }\end{array}$ \\
\hline
\end{tabular}

Fumarolic activity increased at Sherman Crater

Several small avalanches and mudflows moved down Boulder Glacier.

Tephra consisting of hydrothermally altered rock debris erupted from Sherman Crater area.

Two large mudflows moved $11 \mathrm{~km}$ down Boulder Creek valley.

Large avalanche of rock debris moved at least $9 \mathrm{~km}$ down Rainbow Creek valley.

Mudflow extended $14 \mathrm{~km}$ down Park Creek valley

Mudflow moved about $8 \mathrm{~km}$ down Middle Fork Nooksack River valley.

Tephra erupted from Mount Baker ........

Large mudflow moved at least $12 \mathrm{~km}$ down Sulphur Creek valley.

Very large mudflow moved at least $29 \mathrm{~km}$ down Middle Fork Nooksack River valley.

Large mudflow moved $14 \mathrm{~km}$ down Park Creek valley

Mazama ash deposited ..............

Large mudflow moved at least $12 \mathrm{~km}$ down Sulphur Creek valley

Lava flow moved $12 \mathrm{~km}$ down Sulphur Creek valley

Scoria erupted from vent in Sulphur Creek valley

Pyroclastic flows, mudflows, and two lava flows moved down Boulder Creek valley; some reached Baker River valley.

Tephra erupted from Mount Baker .........

Large mudflow reached at least $6 \mathrm{~km}$ down Sulphur Creek valley.

The oldest tephra deposit recognized at Mount Baker is a fine-sand-size, grayish-brown to black ash. Charcoal from an outcrop of this deposit, in the bank of Sulphur Creek $1.8 \mathrm{~km}$ northwest of the Schriebers Meadow cinder cone, was determined to have a radiocarbon age of about 10,350 years (table 3). Mafic minerals in the ash include hypersthene and augite, and associated glass has a refractive index of 1.50-1.55 (table 2). A tephra deposit of similar lithology, 1 or $2 \mathrm{~cm}$ (centimeters) thick, overlies glacial drift and underlies Mazama ash at Heather Meadows northeast of Mount Baker.

The next younger tephra deposit (sample 4, table 2) is thick dark-reddish-brown to yellowish-red scoria that blankets the sides of the Sulphur Creek valley near and southeast of Schriebers Meadow. The scoria on the valley floor is covered by a lava flow, but the deposits are well exposed in cuts along the road to Schriebers Meadow. The scoria was erupted at the site of the
TABLE 2. - Composition of postglacial tephra at Mount Baker

Samples collected by D. R. Crandell and analyzed by R. E. Wilcox and J. W. Babcock twrit ten commun., 1976). Samples arranged in order of relative age, youngest at top of table. M. major constituent $1>10$ percent $) ; x$, minor constituent $t<10$ percent 1 : leaders $1, \ldots 1$, not

\begin{tabular}{|c|c|c|c|c|c|c|c|c|}
\hline $\begin{array}{c}\text { Sample } \\
\text { No. }\end{array}$ & 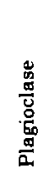 & $\stackrel{\stackrel{\mathscr{D}}{\Sigma}}{\stackrel{\Xi}{\partial}}$ & 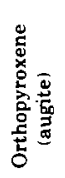 & 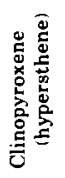 & $\begin{array}{l}\stackrel{\Xi}{\Xi} \\
\stackrel{\Xi}{\Xi} \\
\stackrel{\Xi}{\Sigma} \\
\Sigma\end{array}$ & 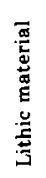 & 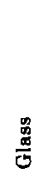 & 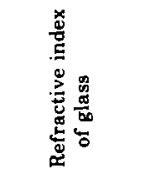 \\
\hline $\begin{array}{l}1 \ldots \ldots \\
2 \ldots \ldots \\
3 \ldots \ldots \\
4 \ldots \ldots \\
5 \ldots \ldots\end{array}$ & $\begin{array}{l}x \\
\times \\
\times \\
\dot{M} \\
X\end{array}$ & $\begin{array}{l}\cdots \\
\cdots \\
x \\
\cdots\end{array}$ & $\begin{array}{l}x \\
x \\
\cdots \\
\cdots \\
x\end{array}$ & $\begin{array}{l}\cdots \\
x \\
x \\
x \\
x\end{array}$ & $\begin{array}{l}x \\
x \\
x \\
x \\
x\end{array}$ & $\begin{array}{l}\mathbf{M} \\
\mathbf{M} \\
\mathbf{M} \\
\ddot{M}\end{array}$ & $\begin{array}{l}x \\
x \\
x \\
\times \\
M\end{array}$ & $\begin{array}{l}1.50-1.51 \\
1.505-1.55 \\
1.55-1.56 \\
1.575 \\
1.50-1.55\end{array}$ \\
\hline
\end{tabular}

SAMPLE DESCRIPTIONS

1. Tephra consisting mostly of particles of altered rock at base of modern forest duff; roadcut $1.5 \mathrm{~km}$ east of highway bridge across the North Fork Nooksack River, about $18 \mathrm{~km}$ northeast of summit of Mount Baker.

2. Post-Mazama ash at Heather Meadows, about $14 \mathrm{~km}$ northeast of summit of Mount Baker.

3. Pre-Mazama ash from vent at Schriebers Meadow, in bank of Sulphur Creek $50 \mathrm{~m}$ south of trail to Baker Pass, about $8 \mathrm{~km}$ south of summit of Mount Baker.

4. Cinders from vent at Schriebers Meadow, same locality as No. 3

5. Ash, dated as about 10,350 years old at same locality as No. 3 forms layer below sample No. 4 and above a mudflow.

TABLE 3. - Radiocarbon dates of samples from postglacial deposits at Mount Baker

(Dates were determined by Meyer Rubin in the radiocarbon laboratory of the U.S. Geologica Survey, except that for $W W-31$, which was determined in the radiocarbon laboratory of Western Washington State College (Burke, 1972)!

\begin{tabular}{|c|c|c|}
\hline Lab. No. & $\begin{array}{c}\text { Date } \\
\text { (years before } \\
\text { present) }\end{array}$ & $\begin{array}{c}\text { Kind of sample and stratigraphic } \\
\text { position }\end{array}$ \\
\hline $\mathbf{W}-3222 \ldots$ & $250 \pm 200$ & $\begin{array}{l}\text { Wood from base of mudflow, } \\
\text { Boulder Creek valley. }\end{array}$ \\
\hline W-2933 $\ldots$ & $530 \pm 200$ & $\begin{array}{l}\text { Wood beneath a mudflow, } \\
\text { Park Creek valley. }\end{array}$ \\
\hline$W-2944 \ldots$ & $5,980 \pm 250$ & $\begin{array}{l}\text { Wood in a mudflow, Middle } \\
\text { Fork Nooksack River } \\
\text { valley. }\end{array}$ \\
\hline $\mathbf{W}-3224 \ldots$ & $6,170 \pm 250$ & $\begin{array}{l}\text { Wood in a mudflow, Park } \\
\text { Creek valley. }\end{array}$ \\
\hline $\mathrm{W}-2971 \ldots$ & $6,650 \pm 350$ & $\begin{array}{l}\text { Wood in same (?) mudflow as } \\
\text { W-3224, Park Creek } \\
\text { valley. }\end{array}$ \\
\hline WW-31 $\ldots$ & $18,700 \pm 1,000$ & $\begin{array}{l}\text { Wood in a mudflow, Boulder } \\
\text { Creek valley. }\end{array}$ \\
\hline$W-2972 \ldots$ & $10,350 \pm 300$ & $\begin{array}{l}\text { Wood in ash-size tephra, } \\
\text { Sulphur Creek valley } \\
\text { (sample 5, table 2). }\end{array}$ \\
\hline
\end{tabular}

The validity of the date obtained on sample WW -31 is questionable because of the small amount of material available for analysis and because of technical problems encountered when the sample was analyzed (Raymond Burke, oral commun.. 1975); thus, the date is tentative.

Schriebers Meadow cinder cone, and its distribution suggests that the wind was from a southwesterly direction during the eruption. Near Schriebers Meadow the deposit is thickest on the north valley wall, and it decreases in grain size and thickness within short distances. Within $1 \mathrm{~km}$ of the source the scoria fragments are as much as $25 \mathrm{~cm}$ in diameter, and the deposit is $50-100 \mathrm{~cm}$ thick; $6 \mathrm{~km}$ to the northeast the fragments 
are of sand size, and the deposit is no more than $3 \mathrm{~cm}$ thick. The scoria directly overlies the 10,350-year-old ash and is older than the Mazama ash. Mafic minerals in the scoria include olivine and augite, and the associated glass has a refractive index of 1.575 (sample 4, table 2). At an outcrop along Sulphur Creek northwest of Schriebers Meadow fine- to medium-sand-size black ash $3-20 \mathrm{~cm}$ thick overlies the scoria. The mineral content of the black ash (sample 3, table 2) resembles that of the scoria; however, the black ash contains abundant lithic material and the scoria does not. No evidence was seen of a significant period of time between deposition of these two tephra units, and they probably resulted from successive eruptions at the vent in Schriebers Meadow.

The thickest and most widely distributed tephra erupted at Mount Baker is a black sand-size ash (sample 2, table 2) that overlies the Mazama ash. The black ash is thickest northeast of Mount Baker, where a maximum of nearly $0.5 \mathrm{~m}$ was noted near Table Mountain, at a distance of about $10.5 \mathrm{~km}$ from the summit of the volcano. At that locality the ash is of fine to coarse sand size (fig. 2). The ash mineralogically resembles the layer that has been dated as about 10,350 years old (table 2). The volume of the black ash is estimated to be $0.1-0.2 \mathrm{~km}^{3}$ (cubic kilometers).

The age of the post-Mazama black ash is known only within rather wide limits. Near Baker Pass the ash overlies a mudflow which is believed to be about 6,000 years old, and the ash is older than a mudflow in the Park Creek valley which is a little more than 500 years old.

A still younger tephra deposit derived from Mount Baker consists of gray to white silt, sand, and rock fragments as much as $10 \mathrm{~cm}$ in diameter (sample 1, table 2). Most of this material seems to have been hydrothermally altered before it was deposited. The tephra contains rock fragments as much as $10 \mathrm{~cm}$ across on Boulder Ridge at a distance of $4 \mathrm{~km}$ from Sherman Crater, and, on that ridge at a distance of 10 $\mathrm{km}$, the tephra deposit is of sand size and 1-3 cm thick. A tephra of similar lithology was noted at scattered localities northeast of the volcano. At a roadcut about $10 \mathrm{~km}$ northeast of the summit of Mount Baker, the deposit is $2-10 \mathrm{~cm}$ thick and contains angular fragments of altered rock. Northeast of the volcano the tephra is discontinuous and highly variable in thickness.

The lithology and distribution of the tephra suggest that it was formed by a series of explosions that threw altered rock fragments from the Sherman Crater area. Because of its variable thickness, the volume of the deposit cannot be accurately estimated. The tephra lies at the grass roots or at the base of forest duff in most

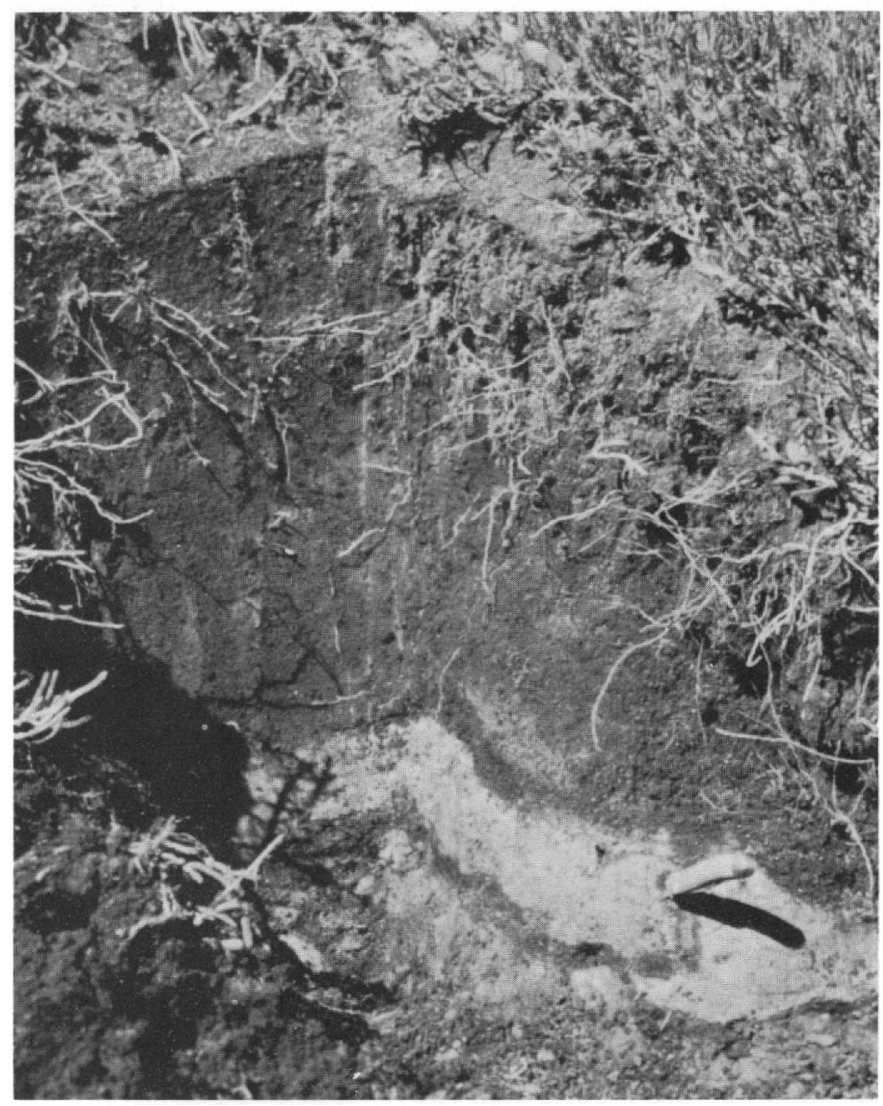

FiguRE 2. - Post-Mazama black ash overlying lighter colored Mazama ash near Table Mountain. Penknife in Mazama ash shown for scale.

areas and overlies the youngest mudflow in the Boulder Creek valley; thus, the tephra is probably no more than 100 or 200 years old.

\section{BOULDER CREEK VALLEY}

During an eruptive period in early postglacial time, a succession of pyroclastic flows, mudflows, and lava flows formed a fill in the Boulder Creek valley which was subsequently trenched by the creek. Remnants of this fill are referred to informally as the Boulder Creek assemblage. The assemblage forms a fan that extends across the Baker River valley, which has been partly in undated by Baker Lake. The original extent of the assemblage down the Baker River valley is not known; correlative deposits were not found in the Skagit River valley near the mouth of Baker River.

The pyroclastic-flow deposits in the assemblage are unsorted mixtures of vesicular and nonvesicular lithic andesite fragments and glassy fragments in a gray silty sand matrix. Most rock fragments are less than $60 \mathrm{~cm}$ in diameter, but a few are as much as $8 \mathrm{~m}$. Deposits of individual pyroclastic flows are $1-8 \mathrm{~m}$ thick and many contain breadcrust bombs. Interbedded deposits thought to be of ash-cloud origin consist of black sand 
as much as $1 \mathrm{~m}$ thick that commonly contains a small amount of pumice and small angular andesite frag. ments.

Mudflows in the assemblage are light gray to tan and are lithologically similar to the pyroclastic-flow deposits; they commonly contain fragments of breadcrust bombs, and virtually all the rock debris in them appears to be fresh and unaltered. Individual mudflows range in thickness from less than $1 \mathrm{~m}$ to more than $10 \mathrm{~m}$ (fig. 3) and generally show a vertical size gradation from coarse at the bottom to fine at the top.

The best exposure of the assemblage is on the north east wall of the Boulder Creek valley, about $1.5 \mathrm{~km}$ upstream from the Baker Lake Road. At least 11 pyroclastic-flow and ash-cloud deposits are interbedded there with 16 mudflows and 2 or 3 fluvial deposits. The lowest unit is $3 \mathrm{~m}$ or more of compact tan silty sand that contains gray andesite rock fragments as large as $1 \mathrm{~m}$ in diameter. Its origin is not known. Overlying it is a 7 $m$-thick succession of at least four crudely stratified mudflows which consist of andesite rock fragments as much as $60 \mathrm{~cm}$ in diameter in a gray silty sand matrix. The oldest pyroclastic-flow deposit seen in the sequence overlies the mudflows and is $1.5-2.5 \mathrm{~m}$ thick; it contains andesite rock fragments and breadcrust bombs in a loose silty sand matrix. The bombs are as large as $1 \mathrm{~m}$ in diameter and have glassy vesicular interiors. Three bombs examined with a fluxgate magnetometer showed a preferred orientation of the direction of remanent magnetism, which indicates that they were hot when the pyroclastic flow came to rest. Discontinuous black sand as much as $1 \mathrm{~m}$ thick overlies the pyroclastic-flow deposit in most places. The sand is fine to coarse and contains scattered rounded fragments of yellow pumice as well as angular fragments of nonvesicular andesite as large as $3 \mathrm{~cm}$ in diameter. The sand is crudely stratified in a few places and probably is an ash-cloud deposit. Interbedded mudflows and pyroclastic-flow deposits make up about the next $25 \mathrm{~m}$ of the assemblage. Individual units are $0.5-8 \mathrm{~m}$ thick and contain both breadcrust bombs and dense andesite fragments. Bouldery as well as fine-grained mudflows 0.5-4 $\mathrm{m}$ thick form the upper $15 \mathrm{~m}$ of the exposure. The deposits are tan to light gray, and some are crudely stratified. Their interbedding and lithologic similarity suggest that the mudflows were formed when water remobilized deposits of the pyroclastic flows soon after they came to rest.

About $1.5 \mathrm{~km}$ farther upvalley a porphyritic andesite lava flow $10-15 \mathrm{~m}$ thick is interbedded with the assemblage (fig. 4). The flow overlies a compact gray mudflow more than $10 \mathrm{~m}$ thick and, in turn, is overlain by mudflows and pyroclastic-flow deposits. A second lava flow of porphyritic andesite overlies these deposits.

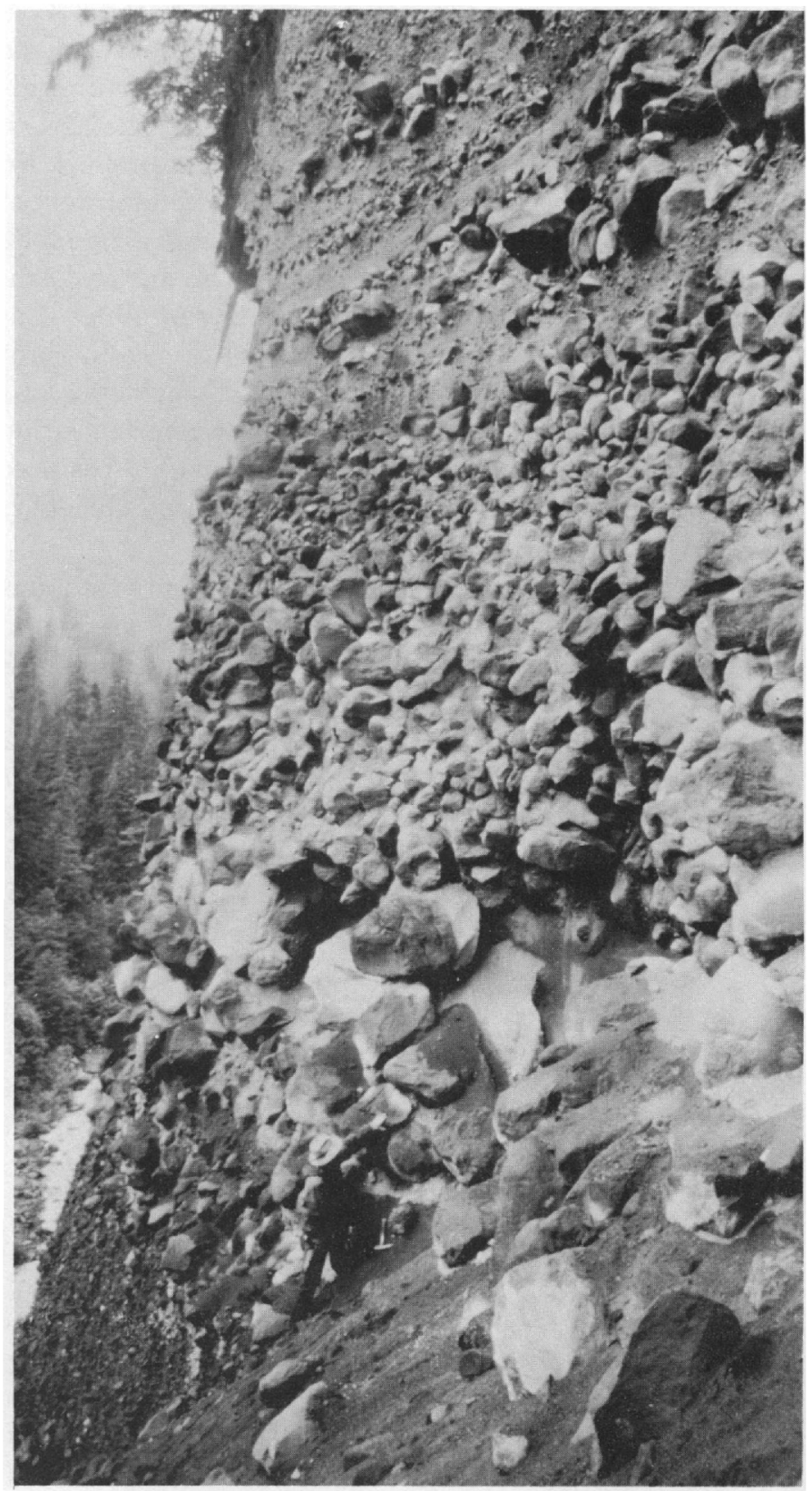

Figure 3. - Bouldery mudflows in the Boulder Creek assemblage Man at lower left shows scale.

Both lava flows extend downvalley at least $5 \mathrm{~km}$ beyond the present terminus of Boulder Glacier.

The largest part of the Boulder Creek assemblage is within the fan that extends across the Baker River valley. Although the altitude of the base of the fan is not known, it probably is not appreciably below 185-200 m, which was the approximate altitude of the Baker River before construction of Upper Baker Dam. The altitude of the apex of the fan is about $310 \mathrm{~m}$. If the fan is assumed to have the shape of one-third of a cone, with an average basal radius of $2.7 \mathrm{~km}$, its volume is $0.28-0.32 \mathrm{~km}^{3}$. The bulk of the assemblage upstream 


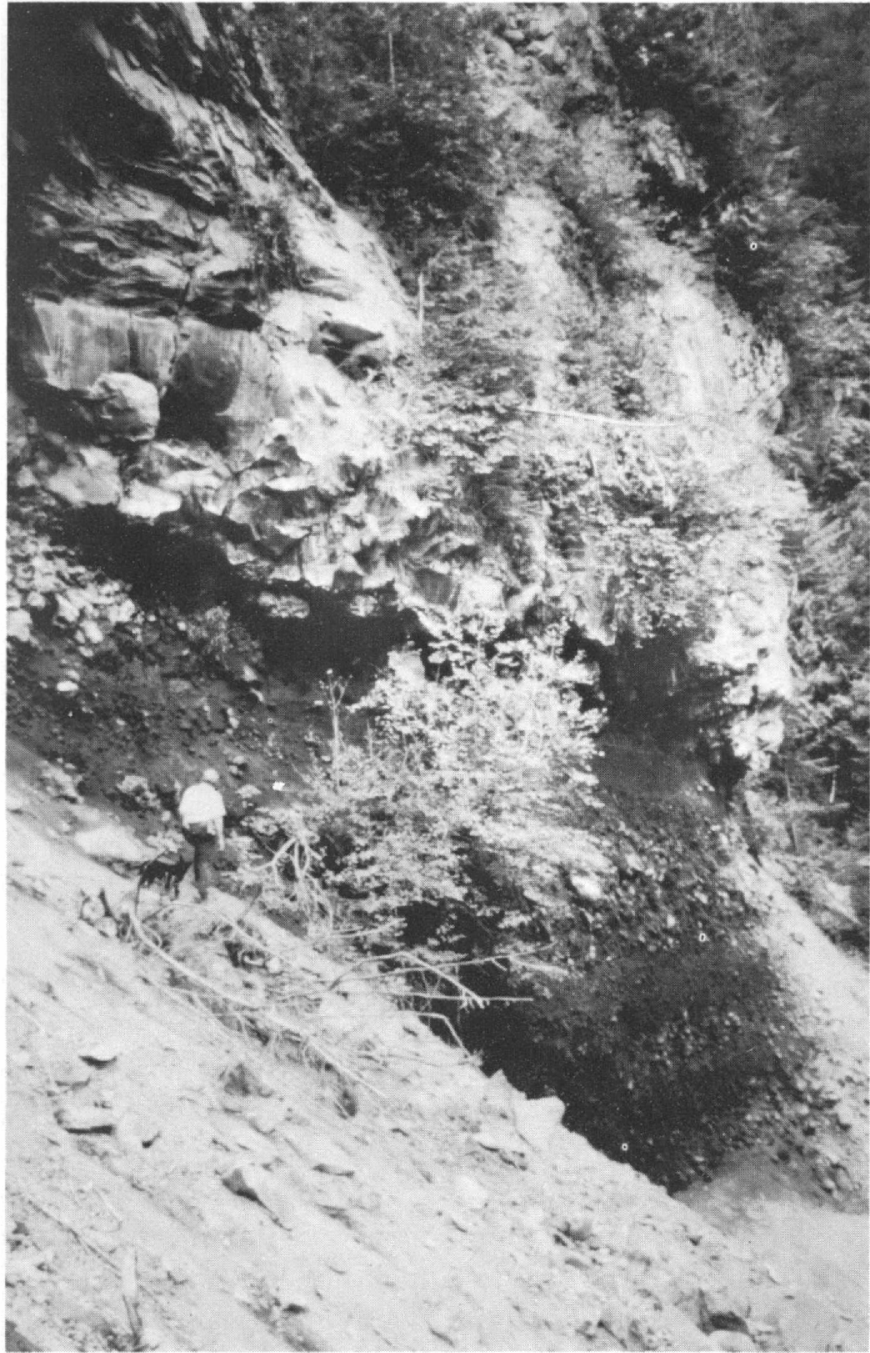

Figure 4. - Andesite lava flow overlying mudflow in the Boulder Creek assemblage.

from the fan occurs within the first $3.2 \mathrm{~km}$ of the valley, where it averages about $325 \mathrm{~m}$ in width and $60 \mathrm{~m}$ in thickness. The volume of this part of the assemblage is estimated to be about $0.06 \mathrm{~km}^{3}$.

The Boulder Creek assemblage evidently was formed during a major eruptive period. The restriction of the pyroclastic-flow deposits to the Boulder Creek valley suggests that they did not result from eruptions at the summit of the volcano, but at Sherman Crater, which is at the head of the Boulder Creek valley. It is possible that Sherman Crater originated during this eruptive period. The absence of hydrothermally altered rock fragments in the Boulder Creek assemblage suggests that the hydrothermal activity common at Sherman Crater today did not commence until after the assemblage was formed.

Stratigraphic relations and one radiocarbon date suggest that the Boulder Creek assemblage was formed during early postglacial time. The deposits are clearly younger than glacial drift formed during the Fraser
Glaciation, which ended about 10,000 years ago (Armstrong and others, 1965; Halstead, 1968; Heusser, 1974). The time when Fraser ice disappeared from the Boulder Creek valley is not known, but by 10,000 years ago the valley was probably free of ice below about $1,200 \mathrm{~m}$, which is the approximate altitude of the outcrop of tephra in the Sulphur Creek valley from which a radiocarbon date of about 10,350 years was obtained (table 3). A radiocarbon sample dated at about 8,700 years (table 3) was obtained by Burke (1972) from a mudflow beneath the lava flow that is interbedded with the assemblage. This date may be representative of the age of most or all of the assemblage, inasmuch as no evidence has been found of intervals of weathering or erosion during its formation.

After the Boulder Creek assemblage was formed, it was trenched by Boulder Creek at least to the depth of the present valley; deposits of two clayey mudflows and bouldery alluvium form a terrace within this trench. The terrace is as much as $10 \mathrm{~m}$ above Boulder Creek in the upper part of the valley, 3-4 m near the Baker Lake Road, and merges with the surface of the Boulder Creek fan about $1 \mathrm{~km}$ downstream from the road.

Two mudflows separated by a soil and duff zone about $8 \mathrm{~cm}$ thick crop out in the south bank of Boulder Creek at and downstream from the Baker Lake Road. The lower mudflow is as much as $3 \mathrm{~m}$ thick and consists of boulders and blocks of andesite as large as $2 \mathrm{~m}$ in diameter in a matrix of gray silty and clayey sand (fig. 5). About 20 percent of the large rock fragments have been hydrothermally altered, and smaller altered fragments are even more abundant. Pieces of wood occur throughout the deposit, and stumps and logs $30-80 \mathrm{~cm}$ in diameter are common near the base of the mudflow. The mudflow overlies more than $1 \mathrm{~m}$ of rusty-brown to gray sand and gravel in which the stumps are rooted. The upper mudflow is lithologically similar to the lower one, but rock fragments in it are no more than $50 \mathrm{~cm}$ in diameter. The upper mudflow is $50 \mathrm{~cm}$ thick near the Baker Lake Road and thins downstream.

Both mudflows seem to be relatively young. A radiocarbon date of about 250 years was obtained from wood taken from the lower mudflow. However, the treering calibration curve of Suess (1970) indicates that a radiocarbon date of 250 years could be equivalent to a calendar date as old as A.D. 1500. The presence of a weathered zone at the top of the lower mudflow, which is overlain by a layer of organic material, suggests that the mudflows were separated by a time interval of one or two centuries' duration. The upper mudflow forms the fan surface and supports a first-generation forest adjacent to the creek. Growth-ring counts of several tree stumps suggest that the forest is not more than 125-150 years old. 


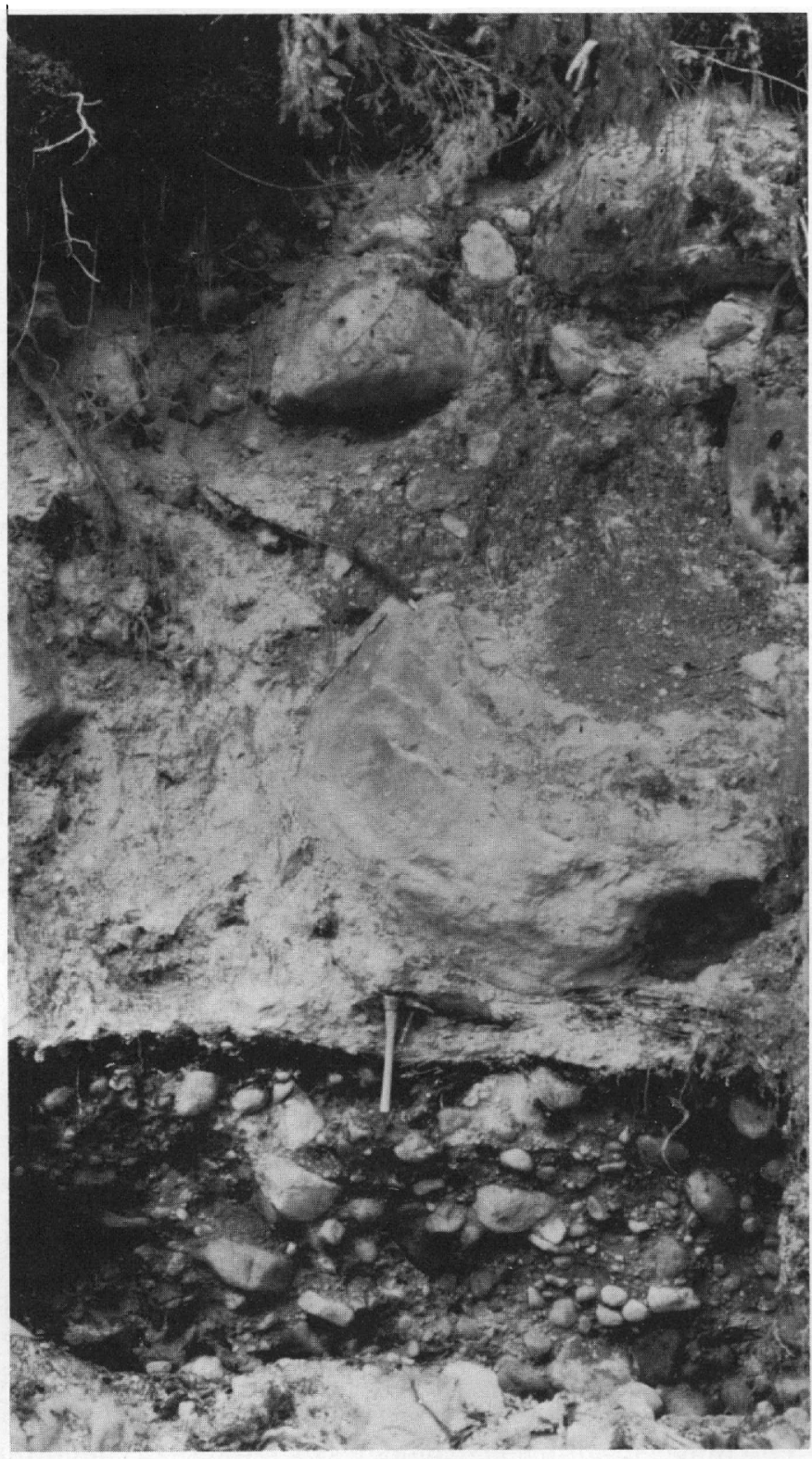

Figure 5. - Light-colored clayey mudflow overlying dark-colored fluvial gravel in bank of Boulder Creek near Baker Lake Road. Pick shown for scale.

\section{PARK CREEK VALLEY}

The only catastrophic events known to have affected the Park Creek valley during postglacial time are represented by two mudflows, which were separated by a long period of time. One of these mudflows crops out on the north side of the Park Creek valley along the road to Baker Hot Spring, about $1 \mathrm{~km}$ northwest of its junction with the Baker Lake Road. The mudflow is bluish gray, has a brown oxidized top, and contains hydrothermally altered rock fragments as much as $2 \mathrm{~m}$ in diameter in a clayey matrix. The deposit is as much as 5 $m$ thick and overlies glacial outwash sand and gravel. A wood fragment from the mudflow yielded a radiocarbon date of about 6,650 years (W-2971, table 3 ). An exposure at Baker Lake of what is probably the same mudflow occurs on the east side of the Park Creek fan near the mouth of Swift Creek, where it is overlain by as much as $2 \mathrm{~m}$ of fluvial sand and gravel which form the surface of the fan. The mudflow contains abundant wood fragments, from which a radiocarbon date of about 6,170 years was obtained.

The mudflow veneers hills and valley walls to heights of $15-20 \mathrm{~m}$ in the lower Park Creek valley, upstream from the Baker Lake Road. The deposit is more than $7 \mathrm{~m}$ thick at the lakeside outcrop. Average thickness is estimated to be $5 \mathrm{~m}$ over an area of $5 \mathrm{~km}^{2}$ (square kilometers) in the lower part of the Park Creek valley. If this estimate is valid, the volume of the mudflow in this part of the valley is about 25 million $\mathrm{m}^{3}$ (million cubic meters). The thickness of the mudflow in the upper part of the valley is not known, but reason. able estimates of area and thickness suggest a volume there of no more than 2 million $\mathrm{m}^{3}$.

After an interval of about 6,000 years, a second clayey mudflow moved down Park Creek and reached the mouth of the valley. The stump of a tree that was growing on the surface covered by this mudflow near the Baker Lake Road yielded a radiocarbon date of about 530 years (W-2933, table 3). Suess' (1970) treering calibration curve suggests that this radiocarbon date is equivalent to a calendar date of about A.D. 1370. The mudflow is mottled gray and rusty brown and contains rock fragments as much as $30 \mathrm{~cm}$ in diameter in a compact matrix of clayey and sandy silt. About 20 percent of the rock fragments are hydrothermally altered. The deposit is well exposed in streambanks at the Baker Lake Road crossing of Park Creek, where it is 1-2 $\mathrm{m}$ thick and overlies several centimeters of carbonized wood fragments and black to brown sand. About $1 \mathrm{~m}$ of fluvial sand and gravel and bedded gray silt underlies the sand. Although the mudflow covered the flood plain to a depth of at least $15 \mathrm{~m}$ at some places, its distribution is limited, and its original volume may have not been more than 1 or 2 million $\mathrm{m}^{3}$.

The clayey mudflows in the Park Creek valley probably were caused by avalanches of hydrothermally altered rock from the northeast flank of the volcano.

\section{RAINBOW CREEK VALLEY}

Within the last few hundred years, several large masses of rock debris have avalanched into the upper part of Rainbow Creek valley, at least one of which moved as far as $9 \mathrm{~km}$. The resulting deposits veneer the valley sides and form hummocky surfaces on the valley floor; shallow basins in the deposits are occupied by small ponds and lakes, the largest of which is Rainbow Lake, about $4.5 \mathrm{~km}$ below the head of the valley. 
About $0.5 \mathrm{~km}$ upvalley from Rainbow Lake the deposits consist of rock fragments as much as $5 \mathrm{~m}$ in diameter in an unstratified reddish-brown silty sand matrix. In some places the matrix is clayey. Rock fragments, fewer than 5 percent of which are hydrothermally altered, are mainly andesite. The surface of the deposits is hummocky and has as much as $15 \mathrm{~m}$ of relief. Steeply sloping ridges of rock debris as much as $40 \mathrm{~m}$ above stream level, which are probably part of the avalanche deposits, are present near the mouth of the creek downstream from Rainbow Falls. The volume of avalanche debris in the Rainbow Creek valley is estimated to be at least 13 million $\mathrm{m}^{3}$.

The avalanche deposits near Rainbow Falls support a first-generation forest. By comparison with trees of known age in the same general area, the oldest trees probably are no more than about 450 years old.

The most recent avalanche deposits in the valley originated when a large mass of rock broke loose from the south valley wall near the terminus of Rainbow Glacier. The resulting rock debris veneers a glacial moraine on the opposite valley wall to a height of $180 \mathrm{~m}$ and extends downvalley at least $1.5 \mathrm{~km}$. This avalanche may have occurred within the last 100 years.

\section{SULPHUR CREEK VALLEY}

The oldest postglacial mudflow from Mount Baker is exposed in the west bank of Sulphur Creek at a point about $1.5 \mathrm{~km}$ northwest of Schriebers Meadow. The deposit consists of more than $2 \mathrm{~m}$ of compact gray silty sand and rock fragments, fewer than 10 percent of which are hydrothermally altered. The mudflow is overlain by a 5 - to $7-\mathrm{cm}$ layer of sand-size gray tephra which contains fragments of charcoal. The radiocarbon age of the charcoal is about 10,350 years (table 3 ).

The sand-size tephra is overlain by $65-70 \mathrm{~cm}$ of reddish-brown to yellowish-red scoria in which individual fragments are as much as $25 \mathrm{~cm}$ across. The scoria was erupted from a vent at Schriebers Meadow, which subsequently was the source of one or more lava flows. A flow from this vent extended $12 \mathrm{~km}$ down the Sulphur Creek valley, forced the Baker River against its east valley wall, and temporarily dammed it. The lava is a dark-gray basaltic andesite (Stavert, 1971) and commonly shows aa structures; some pressure ridges are present near the terminus of the flow.

Stearns and Coombs (1959) found three lava flows in the Baker River valley in the vicinity of Upper Baker Dam and noted that the oldest flow was recognized only in drill holes and seems to be considerably older than the others. It is overlain by till which probably was formed during the last major glaciation of the area. The second lava flow probably is of late glacial age, and the third evidently is postglacial and is correlative with the lava flow in the Sulphur Creek valley.

The stratigraphic relation of the prelava-flow scoria to the sand-size gray tephra shows that the lava flow is less than 10,350 years old, and the presence of Mazama ash on top of the flow indicates an age of more than 6,600 years.

Two clayey mudflows in the Sulphur Creek valley are younger than the scoria and lava flow and are separated from each other by $3 \mathrm{~cm}$ of Mazama ash. The preMazama mudflow consists of gray to reddish-brown silty and clayey sand and rock fragments, a few percent of which are hydrothermally altered. This deposit was seen only at an outcrop along Sulphur Creek $1.5 \mathrm{~km}$ north of the Schribers Meadow cinder cone.

The post-Mazama mudflow is mottled gray to rusty brown and contains more than 10 percent of hydrothermally altered rock fragments in a clayey silt and sand matrix. At the outcrop along Sulphur Creek mentioned above, the mudflow is $1-2 \mathrm{~m}$ thick.

The post-Mazama mudflow forms a widespread veneer on the divide between Easton and Deming Glaciers. In some places it is no more than a few centimeters thick and is recognizable only by its stratigraphic position between tephra layers and by its lithology. Elsewhere, it is at least $7 \mathrm{~m}$ thick. Thin remnants of the mudflow are present at Baker Pass, and others were noted on the east side of a saddle between Cathedral Crag and Park Butte. At this saddle the mudflow veneer extends to a height of nearly $50 \mathrm{~m}$ above the floor of the adjacent basin to the east and indicates that the basin was temporarily filled with mud to this depth. However, because of the steep slopes and the mobility of the mud, most of it drained away southeastward toward Schriebers Meadow. The areal and vertical distribution of this deposit suggests that the mudflow originated in a massive avalanche of hydrothermally altered rock from high on the southwest side of Mount Baker, perhaps from the vicinity of Sherman Peak. If, as seems likely, the Sulphur Creek valley east of Baker Pass was filled with the avalanche/mudflow to the height of the pass, the moving mass may have been more than $200 \mathrm{~m}$ deep. The mass probably moved downvalley as a transient wave in like manner to that inferred for avalanches and mudflows of hydrothermally altered rock debris at Mount Rainier volcano (Crandell, 1971, p. 36, 55). If the avalanche at Mount Baker started in an active hydrothermal area, the clayey material could have had an initially high moisture content from condensation of steam, which would have facilitated movement of the mass far downvalley as a mudflow.

The distribution of the post-Mazama mudflow downvalley from Schriebers Meadow indicates that the mudflow was at least $10 \mathrm{~m}$ deep there during move- 
ment. Still farther downvalley a deposit thought to be the same mudflow underlies a terrace near the Baker Lake Road.

The presence of the post-Mazama mudflow on the divide between Easton and Deming Glaciers suggests that the mudflow in the Sulphur Creek valley is correlative with a large clayey mudflow, described subsequently, that moved down the Middle Fork Nooksack River valley about 6,000 years ago.

Bouldery deposits along Sulphur Creek upsteam from Schriebers Meadow probably were formed by repeated floods and mudflows during the last century or two. These deposits are not clayey and do not contain altered rock fragments. They probably were derived from deposits of glacial drift and were formed during times of high runoff caused by heavy rainfall or rapid snowmelt.

\section{MIDDLE FORK NOOKSACK RIVER VALLEY}

The largest and longest clayey mudflow from Mount Baker originated about 6,000 years ago on the southwest side of the volcano and moved at least $29 \mathrm{~km}$ down the valley of the Middle Fork Nooksack River. The mudflow consists of a mottled gray and rusty-brown mixture of sand, silt, and clay that contains angular and subangular andesite rock fragments, more than 10 percent of which are hydrothermally altered. The deposit underlies terraces along the valley and ranges in thickness from less than $1 \mathrm{~m}$ to more than $15 \mathrm{~m}$. It crops out in roadcuts in the Middle Fork valley near the mouth of Clearwater Creek, where as much as $8 \mathrm{~m}$ of it forms a terrace about $100 \mathrm{~m}$ above the valley floor. At this locality the mudflow contains abundant wood (fig. 6), one fragment of which yielded a radiocarbon date of about 5,980 years $(W-2944$, table 3 ). Near river level in the same area the mudflow is $15 \mathrm{~m}$ thick and contains boulders as much as $1 \mathrm{~m}$ in diameter. The range in altitude of remnants of the mudflow indicates that it was temporarily at least $100 \mathrm{~m}$ deep as it flowed down the Middle Fork valley. The mudflow was also seen near the mouth of Ridley Creek in the upper part of the valley and in streambanks on the west side of Middle Fork $1.5 \mathrm{~km}$ south of the community of Kulshan (fig. 8). The mudflow probably reached at least as far downstream as the mouth of Middle Fork.

At most places the mudflow overlies fluvial sand and gravel or glacial drift, and near Ridley Creek and on the west side of Middle Fork near Kulshan it can be seen to overlie as much as $4 \mathrm{~cm}$ of Mazama ash.

The original volume of the mudflow in the Middle Fork valley is difficult to determine because its exposed thickness is highly variable, and nowhere does it form a broad thick fill; however, the mudflow is estimated to have had an original volume of 40 or 50 million $\mathrm{m}^{3}$.

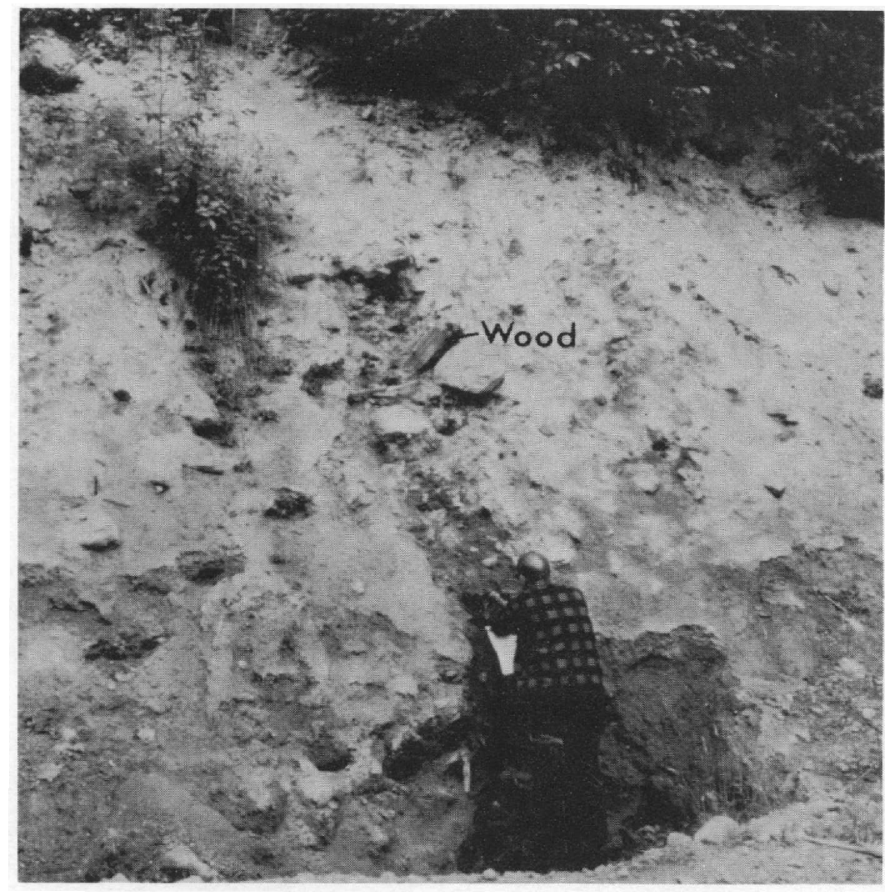

FIGURE 6. - Large clayey wood-bearing mudflow in the valley of the Middle Fork Nooksack River. The radiocarbon age of wood is about 6,000 years

The mudflow probably originated when hydrothermally altered rock debris avalanched from the high southwest side of Mount Baker. The largest part of the avalanche seems to have moved into the headwaters of Middle Fork, but some of it extended into the Sulphur Creek valley.

A younger and much smaller mudflow originated on the southwest flank of Mount Baker and moved about 8 $\mathrm{km}$ down the Middle Fork valley. The deposit forms a broad, hummocky terrace about $15 \mathrm{~m}$ above the flood plain of Middle Fork near the mouth of Ridley Creek, and farther west it displaces the mouth of Rankin Creek nearly $1 \mathrm{~km}$ downstream. The deposit consists mostly of fragments of unaltered volcanic breccia as much as $5 \mathrm{~m}$ in diameter in a matrix of brownish-gray sand and silt. The mudflow probably resulted from the collapse of part of the nearly vertical west valley wall $1-2 \mathrm{~km}$ upvalley from the terminus of Deming Glacier. The deposit is estimated to underlie an area of at least $0.5 \mathrm{~km}^{2}$, to average about $2 \mathrm{~m}$ in thickness, and to have a volume of about 1 million $\mathrm{m}^{3}$. The mudflow is old enough to support a second-generation forest and is younger than the 6,000-year-old mudflow in the Middle Fork valley.

\section{POTENTIAL GEOLOGIC HAZARDS}

Potentially hazardous events that could occur at Mount Baker include the formation of mudflows and avalanches and the eruption of tephra, hot pyroclastic 
flows, and lava flows. Possible dangers associated with each of these phenomena are discussed in the following sections.

\section{MUDFLOWS AND AVALANCHES OF ROCK DEBRIS}

At Mount Baker the greatest potential geologic hazard is rock-debris avalanches from the slopes of the volcano and movement of the resulting masses downvalley either as avalanches or as mudflows. Such avalanches and mudflows could originate without warning and without any associated volcanic activity, although an eruption would greatly increase the probability of such an event.

Mudflows can move at speeds of $15 \mathrm{~km} / \mathrm{hr}$ to more than $30 \mathrm{~km} / \mathrm{hr}$ and bury everything in their path under mud and rock debris. Roads, bridges, and other structures could be destroyed or severely damaged. A mudflow moving into a reservoir would displace an equivalent volume of water and could result in flooding downstream if the reservoir level were high.

The distribution of mudflows that contain hydrothermally altered rock suggests that their source areas were in the Sherman Crater-Sherman Peak area or in the area at the head of Park Glacier on the northeast side of the volcano. Future mudflows presumbly will be caused by avalanches of altered rock from these areas.

An avalanche of rock debris from high on the volcano conceivably could move downslope at a very high speed, like the 1970 avalanche of ice and rock from Huascarán Mountain in Peru (Plafker and others, 1971). That avalanche had a volume of at least 50 million $\mathrm{m}^{3}$ and descended through a vertical distance of about $3,500 \mathrm{~m}$ in traveling $14.5 \mathrm{~km}$. Its average speed over that distance was between 280 and $335 \mathrm{~km} / \mathrm{hr}$. Within a short distance of its source, the avalanche became a highly fluid and mobile mass of mud and boulders. When the main body of the avalanche came to rest, a large destructive wave of water and debris from it traveled more than $135 \mathrm{~km}$ farther downvalley at an average speed of about $35 \mathrm{~km} / \mathrm{hr}$ (Plafker and others, 1971, p. 559).

The only large deposit from Mount Baker which appears to have moved entirely as an avalanche is in the Rainbow Creek valley. That avalanche descended at least $1,740 \mathrm{~m}$ vertically within a distance of about $9 \mathrm{~km}$.

The areas in which a large avalanche of rock debris would have the most serious consequences are in the Boulder Creek valley and Baker Lake. Rock masses having volumes of as much as 30 million $\mathrm{m}^{3}$ could avalanche onto Boulder Glacier from areas both north and south of Sherman Crater. The distance from these potential source areas to the lake is about $12.5 \mathrm{~km}$, and the vertical difference in height is about $2,670 \mathrm{~m}$. The manner of movement and the possible extent of a large avalanche of rock debris from Mount Baker have been analyzed by Shreve (in Frank and others, 1977).

The sliding or falling of rock masses of this size from Mount Baker probably would require an eruption, a steam explosion, or a strong local earthquake. Some of these events probably would also impart an initially high velocity to the mass.

The paths of avalanches from Mount Baker probably would be restricted to areas shown on plate 1 . In addition, a large avalanche moving into Baker Lake could cause one or more waves which would threaten areas along the shoreline and which might overtop the dam if the reservoir level were high.

The events of the last 10,000 years at Mount Baker indicate that large avalanches and mudflows probably will continue to occur in the future, but their size or specific location cannot be reliably predicted. In addition, their average frequency in the future can be estimated if it is assumed that they will occur at the same average rate as in the geologic past. During the last 10,000 years there have been at least eight large avalanches and mudflows of hydrothermally altered rock, including the 6,000-year-old mudflow deposits in the valleys of the Middle Fork Nooksack River and Sulphur Creek as the product of one avalanche (table 4). The mudflows in the Boulder Creek assemblage are arbitrarily excluded from this total because they probably were derived from pyroclastic-flow deposits and were closely associated with eruptions, whereas the avalanches of hydrothermally altered rock could have occurred independent of volcanic activity. If those eight events are divided into the number of years over which they occurred, their average frequency is about one per 1,300 years. However, four of those avalanches and mudflows occurred during the last 600 years, which indicates an average frequency of one per 150 years. If the deposits recognized at Mount Baker accurately reflect the average rate at which avalanches and mudflows occurred in the past, why should the average

TABLE 4. - Large postglacial avalanche and mudflows of altered rock debris from Mount Baker

All deposits listed are mudflows except that in Rainbow Creek valley, which is an avalanche deposit. The 6,000-year-old mudflows in the Sulphur Creek and Middle Fork Nooksack River valleys probably occurred at the same time. (?), unknown|

\begin{tabular}{|c|c|c|c|}
\hline Valley & $\begin{array}{l}\text { Approximate age or } \\
\text { limiting dates } \\
\text { (years ago) }\end{array}$ & $\begin{array}{c}\text { Estimated } \\
\text { minimum } \\
\text { volume } \\
\text { (million } \mathrm{m}^{3} \text { ) }\end{array}$ & $\begin{array}{c}\text { Maximum known } \\
\text { or inferred } \\
\text { length } \\
(\mathrm{km})\end{array}$ \\
\hline Rainbow Creek & $\begin{array}{l}\text { Within last few } \\
\text { centuries. }\end{array}$ & 13 & 9 \\
\hline Boulder Creek & do $\ldots \ldots \ldots$ & (?) & 11 \\
\hline Do. . . . . & do & (?) & 11 \\
\hline Park Creek & 600 & $1-2$ & 14 \\
\hline Sulphur Creek & $6,000(?)$ & $(?)$ & 12 \\
\hline $\begin{array}{l}\text { Middle Fork } \\
\text { Nooksack Ri }\end{array}$ & 6,000 & $40-50$ & 29 \\
\hline Park Creek ... & 6,170 or 6,650 & 27 & 14 \\
\hline Sulphur Creek & $6,600-10,350$ & (?) & 12 \\
\hline Do. & Before 10,350 & (?) & 6 \\
\hline
\end{tabular}


frequency have increased by an order of magnitude during the last 600 years? Possible explanations include the progressive nature of hydrothermal alteration and an increase in the frequency of events that trigger avalanches.

Hydrothermal alteration can so weaken rock that it is easily eroded by ice or water or becomes so unstable that it readily falls or slides from the steep sides of the volcano. Slow piecemeal erosion of weakened rock probably is nearly continuous, and small slides of material occur every few years (Frank and others, 1975). The size of rock masses that fall or slide is partly determined by the distribution and the degree of alteration. With time and continuing hydrothermal activity, rock becomes progressively more susceptible to failure, and the volume of potentially unstable rock increases.

Events that trigger slope failures on volcanoes may be sudden, such as an earthquake, a steam explosion, or an eruption, or the stability of rock in a cliff may be slowly decreased by removal of its support by erosion, by changes in pore-water pressure within the rocks, and possibly by an increase in weight due to snow or water. Although such processes or conditions probably have triggered avalanches in the past, it is not possible to ascribe any prehistoric avalanche or mudflow to a specific cause. Thus, the apparent increase in the average rate of avalanches and mudflows during the last 600 years might have been caused by an increase in frequency of triggering events or by a progressive increase in volume or decrease in strength of weak altered rock, but the data available do not permit a definite answer.

\section{TEPHRA}

Hazards from tephra depend on the volume, rate, and duration of the eruption, the direction and speed of winds, and the distance from the volcano (Wilcox, 1959; Mullineaux, 1974). The direction and speed of winds during a tephra eruption are of paramount importance in determining areas of potential hazard. Deposits $1 \mathrm{~m}$ or more thick could accumulate at distances of many kilometers downwind from the volcano while little or none was falling beyond the flanks of the volcano in the opposite direction.

Tephra can affect human health and property at considerable distances from a volcano by contaminating air, by forming a blanket at the ground surface, and by the abrasive and corrosive effects of the rock particles and accompanying gases. The respiratory system and eyes can be affected by fumes and ash. Tephra can block roads and thus isolate people, increase turbidity and temporary acidity in drinking water, and interrupt telephone, radio, and electrical services. Falling tephra can also cause darkness during daylight hours, which might prevent evacuation of the fallout area and might even lead to panic. Deposition of more than a few centimeters of tephra could impede or halt highway traffic, especially if accompanied or followed by rain. A volcano can emit toxic gases with or without an accompanying eruption of tephra; such gases are quickly diluted and dissipated by winds and rarely occur beyond a volcano in concentrations lethal to humans.

\section{PYROCLASTIC FLOWS}

The main danger from pyroclastic flows results from the basal flow of hot rock debris and an accompanying cloud of hot ash and gases. Pyroclastic flows commonly move at speeds of $50-150 \mathrm{~km} / \mathrm{hr}$ and have temperatures of hundreds of degrees Celsius. Mixtures of hot rock fragments and ash could bury valley floors to depths of many tens of meters, and the cloud of hot ash and gases could cause asphyxiation, burning of the skin, and injuries from impact of rock fragments. Forest fires could be started by the hot debris. Eruption of hot pyroclastic flows onto snowfields or glaciers could result in rapid melting, followed by floods and mudflows. Valley floors would be the areas of greatest danger from the basal flow, and the accompanying cloud of hot ash and gases could extend to heights of hundreds of meters on valley sides. Pyroclastic flows might be directed down one valley by the location or shape of the vent, or they might stream radially down all sides of the volcano.

\section{LAVA FLOWS}

Lava like that erupted by Mount Baker in the past does not directly endanger human life because it seldom flows faster than a person can walk. Lava flows generally result in complete destruction of property in areas they cover. Their indirect effects can be much more widespread than the direct effects. Eruption of lava onto a snowfield or glacier could start disastrous floods and mudflows, and flows that move into forested areas could start fires.

A lava flow similar in size to the one in the Sulphur Creek valley would endanger campgrounds or other developments on the floor of the valley downslope from the vent, perhaps to a distance of at least $15 \mathrm{~km}$. A flow that crossed a road would block it, but the downvalley movement of the flow would be slow enough to permit evacuation of people long before the road was affected. Lava flows could endanger facilities along Baker Lake, but the flows would threaten property rather than lives.

\section{RISK ZONES}

The eruptive behavior of Mount Baker during the last 10,000 years suggests that the eruption of lava flows and pyroclastic flows is less likely in the future than the eruption of tephra and the formation of 


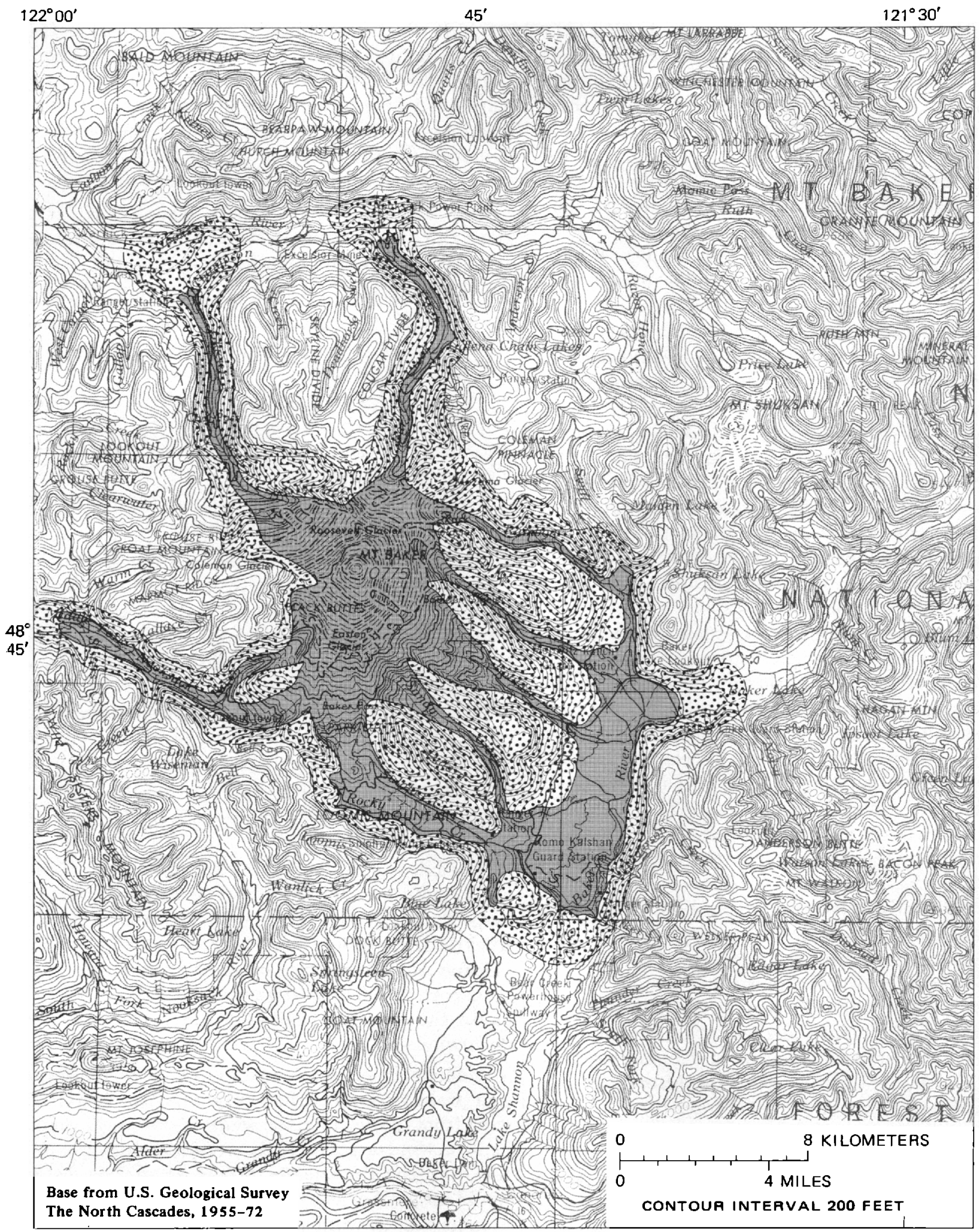

FIGURE 7. - Areas near Mount Baker that could be affected by lava and pyroclastic flows (shaded) and by ash clouds associated with pyroclastic flows (stippled; approximate limit shown by dashed line). 
mudflows and floods; thus, these two general categories of potential hazards are distinguished from one another. Figure 7 shows areas that could be affected by lava flows and pyroclastic flows like those of the last 10,000 years. Only a few valleys were affected in these ways during that period, but the potential risk zones are extended down each valley that heads at the volcano because it is not possible to predict that any one valley is more likely to be affected in the future than others. Lava could be erupted at Sherman Crater, on the flank of Mount Baker, or at a satellite vent beyond the base of the volcano. If an eruption occurs at a satellite vent, it will not necessarily coincide with the Schriebers Meadow cone, which evidently has been inactive for more than 6,600 years. Such a vent presumably could appear anywhere around the base of Mount Baker.

The potential risk zone from ash clouds is shown to extend high on valley walls and farther downvalley than pyroclastic flows or lava flows. This kind of distribution is based on studies of ash-cloud deposits at Mount St. Helens volcano in southwestern Washington (Crandell and Mullineaux, 1973) and on the effects of ash clouds associated with some historic pyroclastic flows elsewhere in the world (Taylor, 1958; Davies, 1972). The actual extent of the areas that would be affected would depend on such factors as volume, speed, and direction of the pyroclastic flow, local topography, and speed and direction of winds.

Areas around the volcano are not subdivided according to various degrees of risk from pyroclastic flows and lava flows, but, in general, relative risk is greatest on the flanks of the volcano and on valley floors within a few kilometers of the base of the volcano. The degree of risk decreases as the distance from the volcano and the height above the valley floors increase.

Zones of relative risk from tephra have not been defined around Mount Baker; instead, on plate 1, lines have been drawn around the volcano that represent the probable maximum amount that would fall as a result of tephra eruptions like the largest of the last 10,000 years. Risk from tephra decreases as the amount decreases, but the specific degree of danger presented by any given amount varies widely for different people, varieties of vegetation, and types of property. For example, an amount that might threaten the life of someone having a respiratory problem might be of little risk to a healthy person. Similarly, some plants can be harmed by tephra thicknesses or gas concentrations that can be tolerated by others, and some machines may be disabled by a tephra fall that does not harm other kinds of machinery. Thus, the potential risk that might be presented by the maximum anticipated tephra fall at a particular place must be evaluated on an individual basis according to the vulnerability of a specific person or group of people, a specific land use, or a specific machine. Such an approach might be most useful in developing awareness in people of the nature and degree of the potential hazard and in helping them plan ways to avoid or mitigate the effects of the hazard. For example, permanent developments that are highly vulnerable to the effects of tephra might be avoided in areas of possible thick tephra fallout.

The areas of possible future tephra deposits of a given thickness shown on the map (pl. 1) are tentative and are based on the following assumptions:

1. That tephra deposits formed in the future will be of similar thickness and volume as the largest deposit of the last 10,000 years, which is the postMazama black ash.

2. That the observed thicknesses of the post-Mazama black ash should be increased by 20 percent to allow for compaction that has occurred since the ash was deposited.

3. That similar thicknesses of tephra could accumulate anywhere around the volcano.

The greater extent of the lines of a given thickness east of the volcano than west is based on wind data (table 5) that indicate winds from the east at various altitudes between 3,000 and $16,000 \mathrm{~m}$ have $40-60$ percent lower mean velocities than those from the west and are less common (fig. 8, table 6). Furthermore, tephra blown toward the west while at high altitudes might, in falling, be carried back to the east by strong westerly winds at lower altitudes. No tephra erupted from Mount Baker Volcano during the last 10,000 years has been recognized in the Skagit River valley or in areas west of the volcano.

The lines representing thicknesses of 35,15 , and 5 $\mathrm{cm}$ on plate 1 do not have any special significance with respect to specific degree of risk. Although tephra thicknesses ideally would decrease away from the volcano in a uniform manner, rainstorms during transport, variable local winds, and other factors could cause the resulting deposit to fluctuate in thickness downwind.

It should be emphasized that any single tephra eruption probably would affect only a narrow sector downwind from the volcano; the width of the sector would depend on wind direction and persistence during the eruption, and the thicknesses falling at various distances would largely be determined by the volume of the eruption, as well as wind strength and direction.

The lines of equal tephra thickness shown on the map are based on very sparse data and are subject to change if future studies indicate that these data and assumptions are incorrect. Nevertheless, the thicknesses shown on the map are believed to be of the 


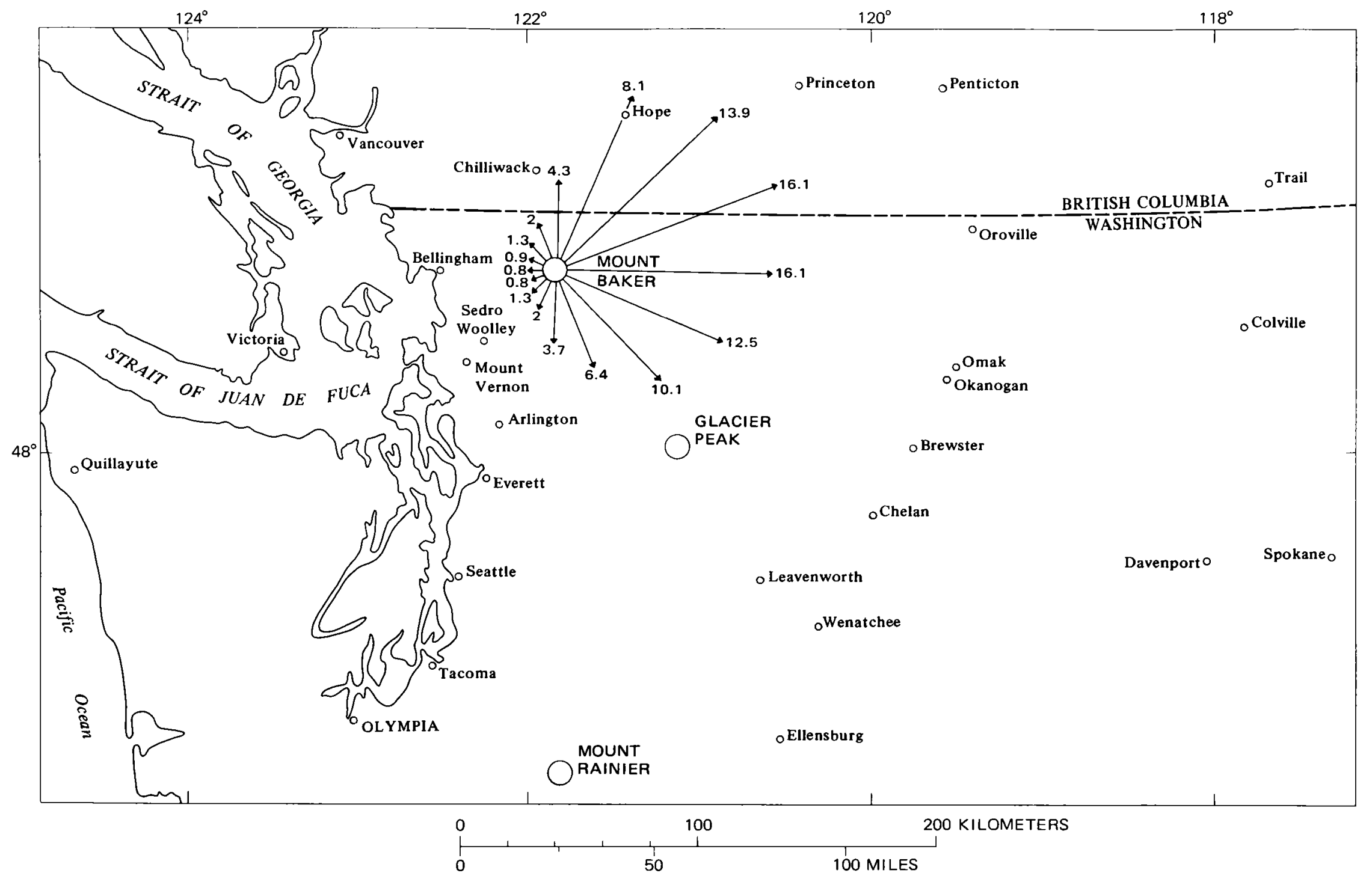

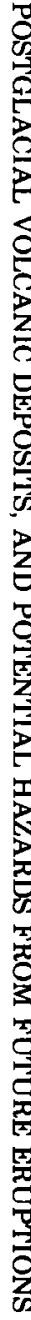

FIGURE 8. - Average frequency of winds in northwestern Washington, which blow toward directions indicated. Length of arrow reflects

percentage of frequency. (See values shown at arrow tips.) Winds are centered on Mount Baker but were determined at Quillayute, Wash., and are based on a 20-year record of winds at altitudes of about $3,000-16,000 \mathrm{~m}$, averaged. Monthly data of percentage of wind directions are shown in table 6 . 
TABLE 5. - Average wind speeds, in knots, at various altitudes

|One $\mathrm{knot}=1.15 \mathrm{mi} / \mathrm{hr}$ or $1.85 \mathrm{~km} / \mathrm{hr}$. Based on 20. year record (1950.70) at Quillayute, Wash. (Winds Aloft Summary of the Air Weather Service, U.S. Air Force, available from the National Climatic Center, Federal Building, Asheville, N.C. 288011)

\begin{tabular}{|c|c|c|c|c|c|c|c|c|c|c|c|c|c|c|c|c|}
\hline $\begin{array}{l}\text { From } \ldots \ldots \ldots \ldots \\
\text { Toward } \ldots \ldots \ldots \ldots\end{array}$ & $\begin{array}{l}N \\
S\end{array}$ & $\begin{array}{l}\text { NNE } \\
\text { SSW }\end{array}$ & $\begin{array}{l}\mathrm{NE} \\
\mathrm{SW} \\
\end{array}$ & $\begin{array}{l}\text { ENE } \\
\text { WSW }\end{array}$ & $\begin{array}{l}\mathbf{E} \\
\mathbf{W}\end{array}$ & $\begin{array}{c}\text { ESE } \\
\text { WNW }\end{array}$ & $\begin{array}{l}\text { SE } \\
\text { NW }\end{array}$ & $\begin{array}{l}\text { SSE } \\
\text { NNW } \\
\end{array}$ & $\begin{array}{l}\mathrm{S} \\
\mathrm{N} \\
\end{array}$ & $\begin{array}{l}\text { SSW } \\
\text { NNE }\end{array}$ & $\begin{array}{l}\text { SW } \\
\mathrm{NE}\end{array}$ & $\begin{array}{l}\text { WSW } \\
\text { ENE }\end{array}$ & $\begin{array}{l}\text { W } \\
\mathbf{E}\end{array}$ & $\begin{array}{l}\text { WNW } \\
\text { ESE }\end{array}$ & $\begin{array}{l}\mathrm{NW} \\
\mathrm{SE}\end{array}$ & $\begin{array}{l}\text { NNW } \\
\text { SSE }\end{array}$ \\
\hline $\begin{array}{l}\text { Approximate } \\
\text { altitude }(m)\end{array}$ & & & & & & & & & & & & & & & & \\
\hline $\begin{array}{l}3,000 \ldots \ldots \\
4,300 \ldots \ldots\end{array}$ & $\begin{array}{l}18.6 \\
26.7\end{array}$ & $\begin{array}{l}16.3 \\
21.7\end{array}$ & $\begin{array}{l}14.8 \\
18.7\end{array}$ & $\begin{array}{l}11.5 \\
15.1\end{array}$ & $\begin{array}{l}11.6 \\
13.7\end{array}$ & $\begin{array}{l}12.4 \\
15.5\end{array}$ & $\begin{array}{l}13.8 \\
18.2\end{array}$ & $\begin{array}{l}18.1 \\
21.5\end{array}$ & $\begin{array}{l}24.2 \\
27.2\end{array}$ & $\begin{array}{l}25.7 \\
30.7\end{array}$ & $\begin{array}{l}25.4 \\
31.3\end{array}$ & $\begin{array}{l}24.2 \\
31.1\end{array}$ & $\begin{array}{l}23.5 \\
31.0\end{array}$ & $\begin{array}{l}21.8 \\
29.4\end{array}$ & $\begin{array}{l}22.4 \\
29.6\end{array}$ & $\begin{array}{l}21.2 \\
28.5\end{array}$ \\
\hline 5,500 & 33.2 & 27.8 & 27.9 & 18.5 & 17.6 & 16.8 & 20.8 & 22.9 & 32.2 & 36.6 & 38.6 & 38.3 & 38.4 & 37.3 & 35.7 & 36.9 \\
\hline 9,100 & 48.6 & 43.8 & 36.5 & 29.9 & 30.2 & 26.4 & 32.2 & 38.0 & 46.8 & 52.5 & 55.9 & 55.4 & 56.2 & 50.8 & 51.6 & 53.9 \\
\hline $\begin{array}{l}12,200 \\
16,200\end{array}$ & $\begin{array}{l}40.9 \\
20.1 \\
\end{array}$ & $\begin{array}{l}31.5 \\
12.4 \\
\end{array}$ & $\begin{array}{l}30.3 \\
11.3 \\
\end{array}$ & $\begin{array}{r}14.9 \\
6.3 \\
\end{array}$ & $\begin{array}{r}19.7 \\
6.4 \\
\end{array}$ & $\begin{array}{r}16.9 \\
9.0 \\
\end{array}$ & $\begin{array}{r}18.8 \\
9.7\end{array}$ & $\begin{array}{l}28.0 \\
13.8\end{array}$ & $\begin{array}{l}35.8 \\
15.5\end{array}$ & $\begin{array}{l}43.8 \\
21.1\end{array}$ & $\begin{array}{l}48.5 \\
23.7 \\
\end{array}$ & $\begin{array}{l}50.3 \\
25.8 \\
\end{array}$ & $\begin{array}{l}50.9 \\
26.2 \\
\end{array}$ & $\begin{array}{l}46.2 \\
25.1 \\
\end{array}$ & $\begin{array}{l}46.3 \\
23.7\end{array}$ & $\begin{array}{l}45.4 \\
21.4 \\
\end{array}$ \\
\hline $\begin{array}{c}\text { Average } \\
\text { wind } \\
\text { speed }\end{array}$ & 31.4 & 25.6 & 23.2 & 16.0 & 16.5 & 16.2 & 18.9 & 23.7 & 30.3 & 35.1 & 37.2 & 37.5 & 37.7 & 35.1 & 34.9 & 34.6 \\
\hline
\end{tabular}

TABLE 6. - Average percentage of wind directions, by month, at altitudes of about 3,000-16,000 m, averaged

[Based on 20-year record (1950-70) at Quillayute, Wash. (Winds Aloft Summary of the Air Weather Service, U.S. Air Force, available from the National Climatic Center, Federal Building. Asheville, N.C. 28801)

\begin{tabular}{|c|c|c|c|c|c|c|c|c|c|c|c|c|c|c|c|c|}
\hline $\begin{array}{l}\text { From } \\
\text { Toward }\end{array}$ & $\begin{array}{l}\mathbf{N} \\
\mathbf{S}\end{array}$ & $\begin{array}{l}\text { NNE } \\
\text { SSW }\end{array}$ & $\begin{array}{l}\text { NE } \\
\text { SW }\end{array}$ & $\begin{array}{l}\text { ENE } \\
\text { WSW }\end{array}$ & $\begin{array}{c}\mathbf{E} \\
\mathbf{W}\end{array}$ & $\begin{array}{c}\text { ESE } \\
\text { WNW }\end{array}$ & $\begin{array}{c}\text { SE } \\
\text { NW }\end{array}$ & $\begin{array}{c}\text { SSE } \\
\text { NNW }\end{array}$ & $\begin{array}{l}\mathrm{S} \\
\mathrm{N}\end{array}$ & $\begin{array}{l}\text { SSW } \\
\text { NNE }\end{array}$ & $\begin{array}{l}\text { SW } \\
\text { NE }\end{array}$ & $\begin{array}{l}\text { WSW } \\
\text { ENE }\end{array}$ & $\begin{array}{l}W \\
E\end{array}$ & $\begin{array}{l}\text { WNW } \\
\text { ESE }\end{array}$ & $\begin{array}{l}\text { NW } \\
\text { SE }\end{array}$ & $\begin{array}{c}\text { NNW } \\
\text { SSE }\end{array}$ \\
\hline $\begin{array}{l}\text { Jan. } \ldots \ldots \\
\text { Feb. } \ldots \ldots \\
\text { Mar. } \ldots \ldots \\
\text { Apr. } \ldots \ldots\end{array}$ & $\begin{array}{l}3.4 \\
3.9 \\
4.5 \\
4.2\end{array}$ & $\begin{array}{l}1.4 \\
1.9 \\
2.1 \\
2.7\end{array}$ & $\begin{array}{l}0.7 \\
1.3 \\
1.1 \\
2.1\end{array}$ & $\begin{array}{r}0.5 \\
.6 \\
.5 \\
1.4\end{array}$ & $\begin{array}{r}0.5 \\
.8 \\
.9 \\
1.2\end{array}$ & $\begin{array}{r}0.2 \\
1.1 \\
.9 \\
1.3\end{array}$ & $\begin{array}{r}0.5 \\
2.0 \\
.9 \\
1.6\end{array}$ & $\begin{array}{l}1.0 \\
1.8 \\
1.5 \\
2.6\end{array}$ & $\begin{array}{l}2.7 \\
3.7 \\
4.3 \\
4.8\end{array}$ & $\begin{array}{l}6.8 \\
6.5 \\
8.4 \\
7.0\end{array}$ & $\begin{array}{l}12.5 \\
10.8 \\
12.2 \\
11.9\end{array}$ & $\begin{array}{l}16.9 \\
14.2 \\
14.2 \\
13.4\end{array}$ & $\begin{array}{l}18.4 \\
16.4 \\
15.5 \\
14.8\end{array}$ & $\begin{array}{l}15.2 \\
15.2 \\
12.7 \\
12.2\end{array}$ & $\begin{array}{l}11.9 \\
12.3 \\
12.8 \\
11.3\end{array}$ & $\begin{array}{l}7.0 \\
7.4 \\
7.6 \\
7.6\end{array}$ \\
\hline $\begin{array}{l}\text { May ... } \\
\text { June ... } \\
\text { July ... } \\
\text { Aug. . . }\end{array}$ & $\begin{array}{l}4.4 \\
3.7 \\
3.1 \\
3.1\end{array}$ & $\begin{array}{l}2.2 \\
2.8 \\
1.9 \\
2.3\end{array}$ & $\begin{array}{l}1.6 \\
2.3 \\
1.4 \\
1.5\end{array}$ & $\begin{array}{l}1.0 \\
1.7 \\
1.0 \\
1.0\end{array}$ & $\begin{array}{r}1.0 \\
1.4 \\
.9 \\
1.0\end{array}$ & $\begin{array}{r}1.6 \\
1.5 \\
.9 \\
1.2\end{array}$ & $\begin{array}{l}3.0 \\
1.7 \\
1.1 \\
1.6\end{array}$ & $\begin{array}{l}3.9 \\
2.8 \\
2.2 \\
2.6\end{array}$ & $\begin{array}{l}6.9 \\
6.0 \\
4.0 \\
5.1\end{array}$ & $\begin{array}{l}8.6 \\
9.0 \\
8.6 \\
9.0\end{array}$ & $\begin{array}{l}13.6 \\
13.9 \\
18.9 \\
15.8\end{array}$ & $\begin{array}{l}15.0 \\
14.9 \\
19.8 \\
17.6\end{array}$ & $\begin{array}{l}13.0 \\
13.4 \\
13.8 \\
14.7\end{array}$ & $\begin{array}{r}10.1 \\
10.0 \\
9.4 \\
10.0\end{array}$ & $\begin{array}{l}7.7 \\
8.6 \\
7.5 \\
8.1\end{array}$ & $\begin{array}{l}6.0 \\
6.2 \\
5.7 \\
5.4\end{array}$ \\
\hline $\begin{array}{l}\text { Sept. . } \\
\text { Oct. . } \\
\text { Nov. . } \\
\text { Dec. . }\end{array}$ & $\begin{array}{l}5.3 \\
2.2 \\
3.3 \\
3.1\end{array}$ & $\begin{array}{l}2.4 \\
1.4 \\
1.4 \\
1.2\end{array}$ & $\begin{array}{r}1.6 \\
.7 \\
.5 \\
.4\end{array}$ & $\begin{array}{r}1.1 \\
.4 \\
.2 \\
.3\end{array}$ & $\begin{array}{r}1.2 \\
.2 \\
.4 \\
.3\end{array}$ & $\begin{array}{l}.8 \\
.2 \\
.4 \\
.3\end{array}$ & $\begin{array}{r}1.2 \\
.5 \\
.8 \\
.5\end{array}$ & $\begin{array}{r}2.2 \\
1.1 \\
1.7 \\
.9\end{array}$ & $\begin{array}{l}3.2 \\
3.8 \\
3.5 \\
3.2\end{array}$ & $\begin{array}{l}7.9 \\
8.7 \\
8.1 \\
8.8\end{array}$ & $\begin{array}{l}12.2 \\
16.6 \\
13.9 \\
14.4\end{array}$ & $\begin{array}{l}12.7 \\
19.9 \\
17.0 \\
17.4\end{array}$ & $\begin{array}{l}14.7 \\
19.2 \\
20.2 \\
18.5\end{array}$ & $\begin{array}{l}14.7 \\
12.5 \\
14.0 \\
14.4\end{array}$ & $\begin{array}{r}11.3 \\
7.8 \\
11.3 \\
10.5\end{array}$ & $\begin{array}{l}7.7 \\
4.6 \\
5.1 \\
6.0\end{array}$ \\
\hline Average & 3.7 & 2.0 & 1.3 & 0.8 & 0.8 & 0.9 & 1.3 & 2.0 & 4.3 & 8.1 & 13.9 & 16.1 & 16.1 & 12.5 & 10.1 & 6.4 \\
\hline
\end{tabular}

right order of mangitude and to represent amounts that could result from a future tephra eruption.

Mudflow- and flood-hazard zones (fig. 8) beyond the flanks of the volcano are limited to valley floors, and the degree of risk varies according to distance from the volcano, height above the stream or river, and the location of areas of hydrothermally altered rock on the volcano. The mudflow-hazard zone would extend down the Baker River valley at least to its mouth, except for the presence of two dams which could trap a mudflow moving down the east side of the volcano. However, if a mudflow or an avalanche moved into one of the lakes rapidly, it could create waves that might endanger people in boats and along shorelines. If lake levels were high, large waves might overtop a dam.

The limits of the flood-hazard zone shown in the Skagit River valley are based on a river discharge of $7,790 \mathrm{~m}^{3} / \mathrm{s}$ (cubic meters per second) The flood-hazard zone in the Nooksack River valley assumes a discharge of $2,350 \mathrm{~m}^{3} / \mathrm{s}$ or $83,000 \mathrm{ft}^{3} / \mathrm{s}$, which is roughly twice the measured discharge at Deming during the largest flood on record, in 1951 (U.S. Army Corps Engineers, 1964).
The areas of potential flood hazard indicate, in general, the extent of flooding that could result from an eruption during a time of unusually high stream discharge. If an eruption occurred during a time of dry weather, excessive melting of snow and ice probably would affect the mudflow-hazard zone and the upstream parts of the flood-hazard zone. However, if an eruption occurred during a time of excessive rainfall or during rapid melting of snow caused by meteorological conditions, major flooding could extend far downstream.

\section{REFERENCES CITED}

Armstrong, J. E., Crandell, D. R., Easterbrook, D. J., and Noble, J. B., 1965, Late Pleistocene stratigraphy and chronology in southwestern British Columbia and northwestern Washington: Geol. Soc. America Bull., v. 76, no. 3, p. 321-330.

Bockheim, J. G., and Ballard, T. M., 1975, Hydrothermal soils of the crater of Mt. Baker, Washington: Soil Sci. Soc. America Proc., v. 39, no. 5, p. 997-10001.

Burke, R. M., 1972, Neoglaciation of Boulder Valley, Mt. Baker, Washington: Bellingham, Wash., Western Washington State Coll. unpub. M.S. thesis, $47 \mathrm{p}$.

Coombs, H. A., 1939, Mt. Baker, a Cascade volcano: Geol. Soc. America Bull., v. 50, no. 10, p. 1493-1509. 
Crandell, D. R., 1971, Postglacial lahars from Mount Rainier volcano, Washington: U.S. Geol. Survey Prof. Paper 677, 75 p.

Crandell, D. R., and Mullineaux, D. R., 1973, Pine Creek volcanic assemblage at Mount St. Helens, Washington: U.S. Geol. Survey Bull. 1383-A, 23 p.

Davies, R. A., 1972, The 1970 eruption, in R. A. Davies, R. W. Johnson, and A. J. R. White, Ulawun volcano, New Britain: Australia Bur. Mineral Resources, Geology and Geophysics Bull. 142 (Bull. PNG 5), p. 17-28.

Easterbrook, D. J., and Rahm, D. A., 1970, Landforms of Washington - The geologic environment: Bellingham, Wash., Western Washington State Coll., Dept. Geology, 156 p.

Frank, David, Meier, M. F., and Swanson, D. A., 1977, Assessment of increased thermal activity at Mount Baker, Washington, March 1975-March 1976: U.S. Geol. Survey Prof. Paper 1022-A, 49 p.

Frank, David, Post, Austin, and Friedman, J. D., 1975, Recurrent geothermally induced debris avalanches on Boulder Glacier, Mount Baker, Washington: U.S. Geol. Survey Jour. Research, v. 3 , no. 1, p. 77-87.

Halstead, E. C., 1968, The Cowichan ice tongue, Vancouver Island: Canadian Jour. Earth Sci., v. 5, no. 6, p. 1409-1415.

Heusser, C. J., 1974, Quaternary vegetation, climate, and glaciation of the Hoh River Valley, Washington: Geol. Soc. America Bull., v. 85 , no. 10 , p. $1547-1560$.

Hyde, J. H., and Crandell, D. R., 1975, Origin and age of postglacial deposits and assessment of potential hazards from future eruptions of Mount Baker, Washington: U.S. Geol. Survey Open-file Rept. 75-286, $22 \mathrm{p}$.

Malone, S. D., and Frank, David, 1975, Increased heat emission from Mount Baker, Washington: EOS (Am. Geophys. Union Trans.), v. 56 , no. 10 , p. $679-685$.

Misch, Peter, 1966, Tectonic evolution of the Northern Cascades of Washington State - A west-cordilleran case history, in A symposium on the tectonic history and mineral deposits of the western Cordillera, Vancouver, B. C., 1964: Canadian Inst. Mining and Metallurgy Spec. Vol. 8, p. 101-148.

Mullineaux, D. R., 1974, Pumice and other pyroclastic deposits in Mount Rainier National Park, Washington: U.S. Geol. Survey Bull. 1326, 83 p.
Plafker, George, Ericksen, G. E., and Concha, J. F., 1971, Geological aspects of the May 31, 1970, Peru earthquake: Seismol. Soc. America Bull., v. 61, no. 3, p. 543-578.

Powers, H. A., and Wilcox, R. E., 1964, Volcanic ash from Mount Mazama (Crater Lake) and from Glacier Peak: Science, v. 144, no. 3624, p. 1334-1336.

Rubin, Meyer, and Alexander, Corrinne, 1960, U.S. Geological Survey radiocarbon dates, [pt.] 5: Am. Jour. Sci. Radiocarbon Supp., v. 2, p. $129-185$.

Stavert, Larry, 1971, A geochemical reconnaissance investigation of Mount Baker andesite: Bellingham, Wash., Western Washington State Coll. unpub. M.S. thesis, 60 p.

Stearns, H. T., and Coombs, H. A., 1959, Quaternary history of the upper Baker Valley, Washington [abs.]: Geol. Soc. America Bull., v. 70 , no. 12 , pt. 2 , p. 1788 .

Suess, H. E., 1970, Bristlecone-pine calibration of the radiocarbon time-scale 5200 B.C. to the present, in I. U. Olsson, ed., Radiocarbon variations and absolute chronology - Proceedings of the 12th Nobel Symposium, held at the Institute of Physics at Uppsala [Sweden] University: New York, John Wiley \& Sons, p. 303-309.

Taylor, G. A. M., 1958, The 1951 eruption of Mount Lamington, Papua: Australia Bur. Mineral Resources, Geology and Geophysics Bull. 38, 117 p.

Thorarinsson, Sigurdur, 1054, The tephra-fall from Hekla on March 29th, 1947, v. 2, pt. 3 of T. Einarsson, G. Kjartansson, and S. Thorarinsson, eds., The eruption of Hekla, 1947-1948: Visindafélag Íslendinga, $68 \mathrm{p}$.

U.S. Army Corps of Engineers, 1964, Flood plain information study, Nooksack River - Summary report: Seattle, Wash., U.S. Army Corps Engineers, 12 p.

1967, Flood plain information study, Skagit River Basin Summary report: Seattle, Wash., U.S. Army Corps Engineers, 17 p.

Wilcox, R. E., 1959, Some effects of recent volcanic ash falls, with especial reference to Alaska: U.S. Geol. Survey Bull. 1028-N, p. $409-476$. 



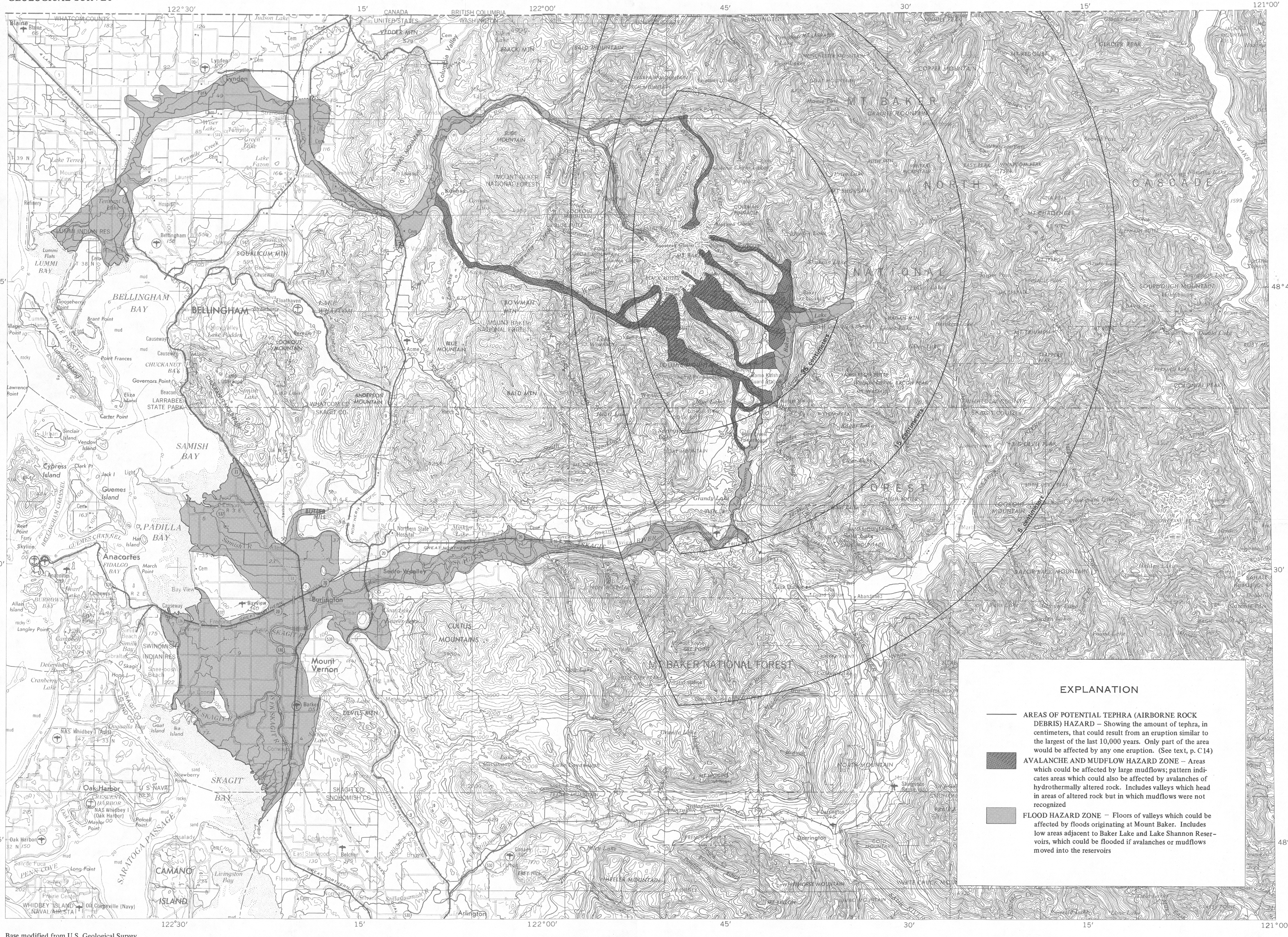


